MAYARA CLEPF BAILONI SANTOS

Desempenho Produtivo e Resíduos no Leite de Vacas Suplementadas com Monensina Sódica nas Rações 


\section{Desempenho Produtivo e Resíduos no Leite de Vacas Suplementadas com Monensina Sódica nas Rações}

Dissertação apresentada ao Programa de PósGraduação em Nutrição e Produção Animal da Faculdade de Medicina Veterinária e Zootecnia da Universidade de São Paulo para obtenção do título de Mestre em Ciências

Departamento:

Nutrição e Produção Animal

Área de Concentração:

Nutrição e Produção Animal

Orientador:

Prof. Dr. Francisco Palma Rennó

Pirassununga 
Autorizo a reprodução parcial ou total desta obra, para fins acadêmicos, desde que citada a fonte.

DADOS INTERNACIONAIS DE CATALOGAÇÃO-NA-PUBLICAÇÃO

(Biblioteca Virginie Buff D’Ápice da Faculdade de Medicina Veterinária e Zootecnia da Universidade de São Paulo)

Santos, Mayara Clepf Bailoni

Desempenho Produtivo e Resíduos no Leite de Vacas Suplementadas com Monensina Sódica nas Rações / Mayara Clepf Bailoni Santos. -- 2011.

$93 \mathrm{f}$.

Dissertação (Mestrado) - Universidade de São Paulo. Faculdade de Medicina Veterinária e Zootecnia. Departamento de Nutrição e Produção Animal, Pirassununga, 2011.

Programa de Pós-Graduação: Nutrição e Produção Animal.

Área de concentração: Nutrição e Produção Animal.

Orientador: Prof. Dr. Francisco Palma Rennó.

1. Vacas leiteiras. 2. Monensina sódica. 3. Digestibilidade aparente total. 4. Produção e composição do leite. 5. Resíduos no leite. I. Título. 
UNIVERSIDADE DE SÃO PAULO

FACULDADE DE MEDICINA VETERINÁRIA E ZOOTECNIA

\section{Comissão de Ética no uso de animais}

\section{CERTIFICADO}

Certificamos que o Projeto intitulado: "Avaliação de diferentes níveis de monensina sódica na alimentação de vacas leiteiras", protocolado sob o n'1879/2010, utilizando 12 (doze) bovinos, sob a responsabilidade do Prof. Dr. Francisco Palma Rennó, está de acordo com os princípios éticos de experimentação animal da "Comissão de Ética no uso de animais" da Faculdade de Medicina Veterinária e Zootecnia da Universidade de São Paulo e foi aprovado em reunião de 20/01/2010.

We certify that the Research "Evaluation of differente levels of sodic monensin in dairy cows rations", protocol number 1879/2010, utilizing 12 (twelve) bovine, under the responsibility Prof. Dr. Francisco Palma Rennó, agree with Ethical Principles in Animal Research adopted by "Ethic Committee in the use of animals" of the School of Veterinary. Medicine and Animal Science of University of São Paulo was approved in the meeting of day 01/20/2010.

São Paulo, 21 de janeiro de 2010

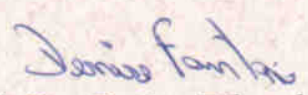

Profa Dra Denise Tabacchi Fantoni

Presidente 


\section{FOLHA DE AVALIAÇÃO}

Nome: SANTOS, Mayara Clepf Bailoni

Título: Desempenho Produtivo e Resíduos no Leite de Vacas Suplementadas com Monensina Sódica nas Rações

Dissertação apresentada ao Programa de PósGraduação em Nutrição e Produção Animal da Faculdade de Medicina Veterinária e Zootecnia da Universidade de São Paulo para obtenção do título de Mestre em Ciências

Data:

\section{Banca Examinadora}

Prof. Dr.

Instituição:

Prof. Dr.

Instituição:

Prof. Dr.

Instituição: 
Aos meus avós, Marisa Rodrigues Clepf e Eneas de Azevedo e Sá, pelo carinho, dedicação, sabedoria, companheirismo e por me darem apoio incondicional nas horas que mais precisei. Somente por eles, se tornou possível a realização de meus sonhos e ideais.

A minha mãe Marília Clepf Bailoni por me dar todo o carinho, incentivo e apoio que necessitei durante toda a vida. Por fazer de mim uma pessoa realizada em meus ideais.

Ao meu pai Marco Aurélio Pereira dos Santos (In memorian) por ter sido o grande incentivador na minha profissão. Sei que onde ele estiver estará orgulhoso por mais essa vitória. Sua perda me deu forças para lutar cada vez mais pelos meus sonhos e hoje tenho uma parte desse sonho realizada.

Aos meus padrinhos Márcia e Paulo Henrique por todo apoio e por confiarem na minha capacidade.

A minha prima Luísa e Tio Clayton por estarem sempre presentes em minha vida e em todas as horas, sendo elas boas ou ruins.

Dedico esse trabalho com imensa gratidão 


\section{AGRADECIMENTOS}

Agradeço, primeiramente a Deus, por tornar possível meus sonhos.

Agradeço a minha família, por me apoiarem e incentivarem. Pela sabedoria a que me guiaram e continuam guiando pelos caminhos da vida, sempre me ensinando o discernimento e conduzindo para caminhos certos.

À Universidade de São Paulo, Faculdade de Medicina Veterinária e Zootecnia e ao Departamento de Nutrição e Produção Animal, pela oportunidade da realização do meu mestrado.

À Fundação de Amparo à Pesquisa do Estado de São Paulo - FAPESP, pela concessão da bolsa de estudo, que gerou tranqüilidade e possibilitou a dedicação exclusiva a esse trabalho.

À empresa Tortuga pela concessão do auxílio à pesquisa que resultou na realização deste estudo.

Ao meu orientador Prof. Dr. Francisco Palma Rennó, pela oportunidade de realização deste estudo, pela confiança em minha capacidade, pela sabedoria e ensinamentos. Pela competência, orientação, profissionalismo, paciência e dedicação. Por todas as conversas e críticas que foram muito produtivas em minha vida. Reconheço hoje o quanto cresci pessoalmente e profissionalmente e muito disso devo ao meu orientador, por ter me apoiado quando precisei e ter me repreendido quando estava errada. Afinal, errando é que se aprende e agradeço muito a oportunidade de ter feito parte de sua equipe.

Ao Carlinhos, por todos os ensinamentos e ajuda indispensável para a realização do estudo.

As grandes amigas Beatriz (Bixuka) e Ana Paula, por todo o companheirismo, dedicação, paciência, apoio e amizade. Por todas as horas de conversas, risadas, desabafos, 
desesperos e de alegrias. Obrigada por você fazer parte da minha vida. A vida nos tornou amigas e o coração nos tornou irmãs.

Ao José Esler, por tornar possível esse estudo e suas análises. Pela ajuda e dedicação que foi imprescindível. Pelas horas de conselhos e conversas. Por ter se tornado um amigo tão especial.

À amiga Esther por toda a paciência e amizade. Por ter me recebido tão bem aqui e sempre ter me ajudado.

À amiga Lenita por todas as horas de conversa e conselhos, por sempre me apoiar e ajudar.

À Cybele e Gabriella por em tão pouco tempo de convivência terem se tornado pessoas tão importantes em minha vida, sempre me apoiando e me ajudando.

Aos professores do Departamento de Nutrição e Produção Animal pelos ensinamentos.

Aos funcionários da fábrica de ração da Cordenadoria, Srs. Cláudio, Israel e José Luiz, agradeço a atenção dispensada.

À secretaria de pós graduação do departamento VNP, Alessandra, João Paulo e Fábia. Sempre dispostos a ajudarem e colaborarem conosco.

A equipe do Laboratório de Pesquisa em Bovinos, Flávio, Thaíssa, Jefferson, Rafael (Bisão), Rodolfo (Badá), Vitor, Mineirinho, Tio Carlão, Justino, Lenon, Paulo e Jota pela ajuda incondicional.

Ao Gustavo (Sacudo) e Rodrigo (Komixão) por tornarem meus dias sempre alegres com suas brincadeiras. Às vezes irritantes, porém muito especiais.

Aos laboratórios do Departamento de Nutrição e Produção Animal, Sr. Ari, Sr. Gilson, Everson, Simi e Lucinéia, que tornaram possível as análises e resultados desse estudo.

Aos amigos do VNP: Maria Fernanda, Babi, Erika, Claudinha, Carol Tobias, Camila (Fede), Rinaldo, Rafael, Larissa, Tácia, Juliane Diniz, Jú Praia, Marina, Nara, Marília, 
Mariana, Débora, Mariana, Camila Raineri, Maurício (Xibungo), Eduardo (Frodo), Tarley, Daniela, Nara (Leite), Luís Henrique, Paula, Danilo, Iaçanã, Bruno (Xacrete), Rui (Libido), Laura, Alejandro, Nayara, Francine, João (Pé de pano), Lara, Dorf, Caio (Lucas), Pedro, Teresa (Novilha), Nataly (Bereba), Thiago (leite), Thiago (eqüinos), Flávio (Perna), Diego, Kazu, Leonardo, Thiago (Piracicaba), Cícero, Paulinho, Paraná, Salete, Júlia e Juliana Osório. Aos amigos do VRA: Thiago (Arroz), Milton, Daniela, Moana, Kleber, Zé Rodrigo, Henrique e Juliane.

Aos alunos de iniciação científica e estagiários, Kessia, Eduarda, Finfa, Bumba, Katimbó, Baranga, Pernilongo, Porca, Danilo (ku Seco), Põe, Caçapa, Bisonha, Japa, Stephanie (Jolie), Thais (Pira), Maísa, Kumi, Fininho, Jurema, entre muitos que passaram pelo LPBL e ajudaram de forma efetiva para realização dos experimentos.

Agradeço aos funcionários da limpeza, por todos os “bom dia” e por tornarem possível o trabalho nos laboratórios. 
"E mesmo que meus passos sejam falsos, mesmo que os meus caminhos sejam errados, mesmo que meu jeito de levar a vida incomode, eu sei quem sou... E sei pelo que devo lutar, e se você acha que meu orgulho é grande, é porque nunca viu o tamanho da minha fé."

(Tião Carreiro) 


\section{RESUMO}

SANTOS, M. C. B. Desempenho produtivo e resíduos no leite de vacas suplementadas com monensina sódica nas rações. [Productive performance and milk residues in dairy cows supplemented of sodic monensin in the rations]. 2011. 93 f. Dissertação (Mestrado em Ciências) - Faculdade de Medicina Veterinária e Zootecnia, Universidade de São Paulo, Pirassununga, 2011.

O objetivo deste estudo foi avaliar diferentes concentrações de monensina sódica na ração de vacas em lactação e seus efeitos sobre o consumo e digestibilidade aparente total da matéria seca e dos nutrientes, produção e composição do leite, fermentação ruminal, síntese de proteína microbiana, parâmetros sanguíneos e resíduos de monensina no leite. Foram utilizadas 12 vacas da raça Holandesa, distribuídas em três quadrados latinos 4x4 balanceados, alimentadas com as seguintes rações: 1) Controle (C), composto por ração basal sem adição de monensina, 2) Monensina 12 (M12), adição de 12 mg/kg MS de monensina na ração, adicionada ao concentrado, 3) Monensina 24 (M24), adição de 24 mg/kg MS de monensina na ração, adicionada ao concentrado e 4) Monensina 48 (M48), adição de 48 $\mathrm{mg} / \mathrm{kg}$ MS de monensina, adicionada ao concentrado. A produção de leite e o consumo de matéria seca foram mensurados diariamente durante todo o período experimental. As amostras utilizadas para análise da composição do leite foram coletadas no $16^{\circ}$ dia de cada período experimental, sendo provenientes das duas ordenhas diárias. As amostras de sangue foram coletadas em tubos vacuolizados por punção da veia e/ou artéria coccígea. As amostras de líquido ruminal foram coletadas com a utilização de sonda esofágica três horas após a alimentação matinal. A digestibilidade foi determinada por meio de indicador interno FDAi. Houve efeito linear decrescente do consumo de matéria seca, matéria orgânica, proteína bruta, extrato etéreo, carboidratos totais, fibra detergente neutro, carboidratos não fibrosos e nutrientes digestíveis totais. Não houve diferença na digestibilidade aparente total da matéria seca e dos nutrientes em função das rações experimentais, excetuando-se a digestibilidade aparente total da proteína bruta e fibra detergente neutro, que foram observados efeitos linear 
crescente e decrescente, respectivamente. Não houve efeito das rações experimentais sobre os valores de $\mathrm{pH}$ ruminal. A suplementação com monensina sódica nas dietas resultou em alteração da proporção molar de propionato no líquido ruminal, além de diminuir a relação acetato:propionato. As rações contendo monensina sódica apresentaram maior proporção molar de propionato e menor de acetato em relação à ração controle, e, de forma semelhante, apresentaram menor relação acetato:propionato. Não houve efeito das dietas experimentais nas excreções diárias totais de urina, de alantoína e de acido úrico na urina, e de derivados de purinas totais. Não houve diferença na porcentagem de alantoína nos derivados de purina, das purinas absorvidas e do nitrogênio microbiano para as rações experimentais. Foi observado aumento de produção de leite para as vacas alimentadas com as concentrações intermediárias de monensina sódica nas rações. Não houve efeito da adição de monensina sódica nas rações sobre os parâmetros sangüíneos glicose, colesterol total, proteína total, albumina, aspartato aminotransferase e $\gamma$-glutamiltransferase. Foi observado efeito linear crescente com a adição de monensina sódica nas rações sobre a uréia e nitrogênio uréico do soro. Os resíduos de monensina sódica detectados no leite estão dentro do limite máximo estabelecido pela FAO/WHO. A utilização de monensina sódica nas rações de vacas leiteiras no terço médio de lactação influencia o desempenho produtivo dependendo da dose utilizada, e não resulta em resíduos no leite independentemente da dose utilizada.

Palavras-chave: Vacas leiteiras Monensina sódica Digestibilidade aparente total Produção e composição do leite Resíduos no leite. 


\begin{abstract}
SANTOS, M. C. B. Productive performance and milk residues in dairy cows supplemented of sodic monensin in the rations. [Desempenho produtivo e resíduos no leite de vacas suplementadas com monensina sódica nas rações]. 2011. 93 f Dissertação (Mestrado em Ciências) - Faculdade de Medicina Veterinária e Zootecnia, Universidade de São Paulo, Pirassununga, 2011.
\end{abstract}

This aim this study was evaluate the use of different concentrations of sodic monensin the feed of dairy cows and its effects on consumption and total apparent digestibility of dry matter and nutrients, milk yield and milk composition, ruminal fermentation, synthesis microbial protein, blood parameters and sodic monensis residues in milk. Twelve Holstein cows were allocated in three balanced Latin squares $4 \times 4$, and fed with the following rations: 1) control (C), basal diet without sodic monensin addition, 2) monensin 24 (M24), addition of $24 \mathrm{mg} / \mathrm{kg} \mathrm{DM}$ of monensin in the ration, added to concentrate, and 3) monensin 48 (M48), addition of $48 \mathrm{mg} / \mathrm{kg}$ DM of monensin in the ration, added to concentrate. Milk yield and dry matter intake were measured daily throughout the experimental period. The samples used for analysis of milk composition were collected on the $16^{\text {th }}$ day of each period, and from the two milkings. Blood samples were collected in vacuolated tubes by puncture or coccygeal vein or artery. Samples of rumen fluid were collected with use of esophageal probe three hours after the morning feeding. The digestibility was determined by means of an internal indicator iADF. There was linear effect dry matter intake, organic matter, crude protein, ether extract, total carbohydrates, neutral detergent fiber, non-fiber carbohydrates and total digestible nutrients. There was no difference on apparent total tract digestibility of dry matter, organic matter, ether extract, total carbohydrates, non-fiber carbohydrates and total digestible nutrient values observed for the experimental diets. There was no difference in total apparent digestibility of dry matter and nutrients depending on the experimental diets, except for the total apparent digestibility of crude protein and neutral detergent fiber, wich effects were observed linear ascending and descending, respectively. There was no effect for ruminal $\mathrm{pH}$ 
values. Supplementation with sodic monensin in the diets resulted inchanging the molar proportion of propionate in ruminal fluid while decreasing the acetate:propionate. The rations containing monensin had higher molar ratio of acetate propionate and smaller relation to the control diet and similary had a lower acetate:propionate ratio. There was no effect in total daily urine excretion of allantoin and uric acidin urine and total purine derivates. There was no difference in the percentage of allantoin in the purine derivates, absorbed purines and microbial nitrogen to the experimental diets. We observed increase in milk yield for cows fed the intermediate concentration of monensin in the feed. There was no effect of monensin in feed on the blood parameters glucose, total cholesterol, total protein, albumin, aspartate aminotransferase and y-glutamyltransferase. Increased linearly, with the addition of monensin in the feed on the urea and serum urea nitrogen. The detected residues of sodic monensin in milk was smaller that the maximum limit established for FAO/WHO. The use of monensin in diets cows in the middle third of lactation influences growth performance depending on the dose used, and does not result in residues in milk regardless of dose.

Key words: Dairy cows Sodic monensin Total apparent digestibility Milk yield and milk composition Residues in milk. 


\section{LISTA DE TABELAS}

Tabela 1 - Proporção dos ingredientes do concentrado, expressa na matéria seca $(\% \mathrm{MS})$......

Tabela 2 - Composição bromatológica do concentrado experimental .......................... 48

Tabela 3 - Composição bromatológica das dietas experimentais............................... 49

Tabela 4 - Composição químico-bromatológica dos nutrientes do concentrado e da silagem de milho.

Tabela 5 - Médias ajustadas e erro padrão da média (EPM) do consumo de matéria seca (CMS) e nutrientes, em função das rações experimentais.

Tabela 6 - Efeito das rações experimentais sobre a digestibilidade aparente total da matéria seca e nutrientes.

Tabela 7 - Médias ajustadas e erro padrão da média (EPM) do $\mathrm{pH}$, concentrações de nitrogênio amoniacal $\left(\mathrm{N}-\mathrm{NH}_{3}\right)$, proporção e concentração molar e total de ácidos graxos de cadeia curta (AGCC) no líquido ruminal, três horas após a alimentação, segundo as rações experimentais.

Tabela 8 - Médias ajustadas e erro padrão da média (EPM) das concentrações de alantoína na urina (Alantoína) e do ácido úrico, concentrações de alantoína no leite (ALAL), das purinas microbianas absorvidas (Pabs), da alantoína em porcentagem de purinas totais (ALA:DP), da excreção total de urina (ETU), do nitrogênio microbiano (Nmic) e da eficiência de síntese de proteína microbiana, em função das rações experimentais

Tabela 9 - Eficiência de utilização e balanço de energia, em função das rações experimentais

Tabela 10 - Médias e erro padrão da média (EPM) dos compostos nitrogenados totais (NT), excreção de compostos nitrogenados nas fezes (N-fezes), na urina (N-urina) e no leite (N-leite), balanço de nitrogênio e eficiência da utilização de nitrogênio, em função das rações experimentais.

Tabela 11 - Médias e erro padrão da média (EPM) da produção diária de leite, sem (PL) e com correção para 3,5\% de gordura (PLC), teores e produção diária no leite de gordura, proteína bruta, uréia (URL), nitrogênio uréico no leite (NUL), peso corporal, eficiência produtiva (EP), escore de condição corporal (ECC) e mudança de escore de condição corporal (MECC), em função das rações experimentais.

Tabela 12 - Médias e erro padrão da média (EPM) das concentrações de glicose (GLI), colesterol total (COT), colesterol HDL (C-HDL), uréia (URE), nitrogênio uréico no soro (NUS), proteínas totais (PTN) e albumina, em função das rações experimentais. 


\section{LISTA DE ABREVIAÇÕES E SIGLAS}

CMS Consumo de matéria seca

CT Carboidratos totais

ED Energia digestível

EE Extrato etéreo

$E_{L} \quad$ Energia líquida de lactação

FDN Fibra em detergente neutro

MO Materia orgânica

M12 Ração experimental $12 \mathrm{mg} / \mathrm{kg}$ MS de monensina

M24 Ração experimental 24 mg/kg MS de monensina

M48 Ração experimental 48 mg/kg MS de monensina

MS Matéria seca

$\mathrm{N}-\mathrm{NH}_{3} \quad$ Nitrogênio amoniacal 


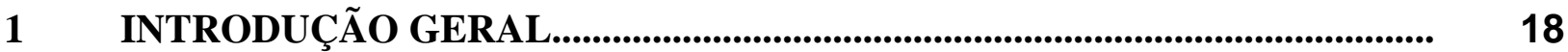

$2 \quad$ HIPÓTESE E OBJETIVOS..................................................................................... 21

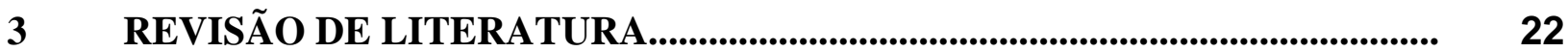

3.1 IONÓFOROS NA ALIMENTAÇÃO DE RUMINANTES..................................... 22

3.2 MONENSINA SÓDICA NA ALIMENTAÇÃO DE VACAS LEITEIRAS............... 27

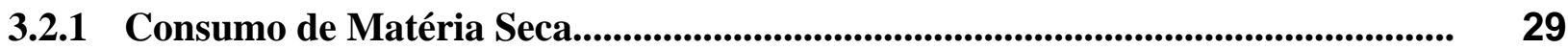

3.2.2 Digestibilidade Aparente Total...................................................................... 31

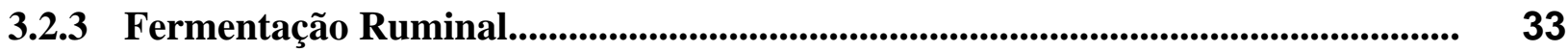

3.2.4 Síntese de Proteína Microbiana................................................................................ 38

3.2.5 Produção e Composição de Leite.................................................................................... 39

3.2.6 Parâmetros Sanguíneos.............................................................................................. 43

3.2.7 Resíduos de Monensina Sódica no Leite.................................................................... 44

4 MATERIAL E MÉTODOS.................................................................................... 46

4.1 LOCAL, INSTALAÇÕES E ANIMAIS........................................................ 46

4.2 RAÇÕES EXPERIMENTAIS E ANÁLISE DE ALIMENTOS........................... 46

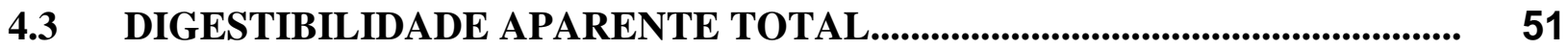

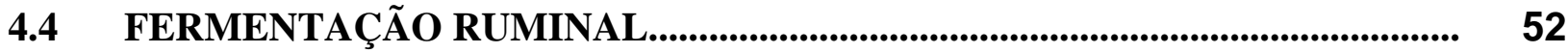

4.5 SÍNTESE DE PROTEÍNA MICROBIANA............................................................ 54

4.6 BALANÇO DE NITROGÊNIO E ENERGIA.................................................... 55

4.7 PRODUÇÃO E COMPOSIÇÃO DE LEITE.................................................... 58

4.8 AVALIAÇÃO DE ESCORE DE CONDIÇÃO CORPORAL E PESO CORPORAL ............................................................................................................... 59

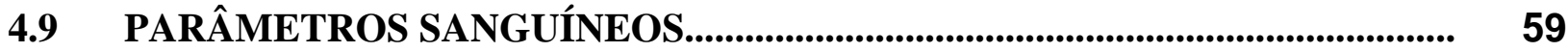

4.10 RESÍDUOS DE MONENSINA SÓDICA NO LEITE..................................... 61

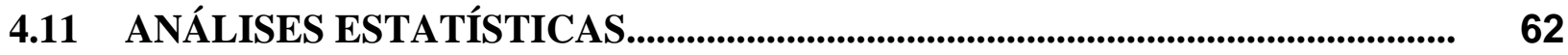




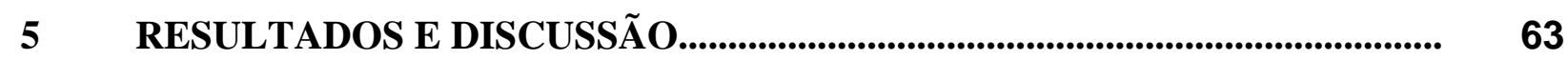

5.1 CONSUMO................................................................................................................... 63

5.2 DIGESTIBILIDADE APARENTE TOTAL........................................................... 65

5.3 FERMENTAÇÃO RUMINAL............................................................................... 67

5.4 SÍNTESE DE PROTEÍNA MICROBIANA.......................................................... 70

5.5 BALANÇO DE ENERGIA E NITROGÊNIO....................................................... 72

5.6 PRODUÇÃO E COMPOSIÇÃO DE LEITE............................................................ 75

5.7 PARÂMETROS SANGUÍNEOS............................................................................ 78

5.8 RESÍDUOS DE MONENSINA SÓDICA NO LEITE................................................ 81

6 CONCLUSÕES..................................................................................... 83

REFERÊNCIAS........................................................................................... 84 


\section{INTRODUÇÃO GERAL}

A utilização de ionóforos é permitida em diversos países para a utilização em bovinos de corte e em animais explorados para a produção de leite. Diversos países como o Brasil, Austrália, Nova Zelândia, Canadá, Estados Unidos e vários países da Europa liberaram a utilização deste produto para vacas leiteiras (PLAZIER et al., 2000; NRC, 2001).

O motivo destes ionóforos aumentarem o desempenho de animais é atribuído principalmente a melhora da eficiência energética devido ao aumento da digestibilidade dos alimentos, ao aumento da produção do ácido propiônico, devido a redução da relação acetato/propionato, diminuição da produção de metano, diminuição da produção de ácido láctico, e por reduzir as perdas de proteína e aminoácidos que seriam potencialmente fermentados em nível de rúmen a produção de amônia (RUSSELL ; STROBEL, 1989).

Segundo o NRC (2001) a utilização de ionóforos (monensina e lasolacida) para animais não lactantes tem aumentado a eficiência alimentar, são úteis na prevenção da coccidiose e aumentam o ganho de peso. Heinrichs e Bush (1991) demonstraram que há uma redução da severidade de coccidioses quando bezerros são alimentados com dietas contendo ionóforos.

Van Soest (1984) cita que os ionóforos são mais efetivos em reduzir a degradação protéica em dietas que contém fontes de concentrados rapidamente degradáveis do que dietas baseadas em feno ou em silagens devido às proteínas solúveis destes alimentos terem altas concentrações de nitrogênio não protéico quando comparados com alimentos concentrados.

Também, efeitos adicionais da produção aumentada de glicose estão o maior número de aminoácidos disponíveis para a gliconeogênese e a alteração do status hormonal, que podem modificar a partição dos nutrientes e a composição do leite (NRC, 2001). 
Segundo Kennelly e Lien, (1997 apud NRC, 2001), a composição de gordura no leite geralmente diminui $0,1 \%$ ou mais, a percentagem de proteína tem resposta variável. No entanto, Phipps et al. (2000) cita que estas diminuições de gordura no leite são aliviadas quando aumenta-se a relação volumoso:concentrado na dieta.

O consumo de matéria seca geralmente é muito variável em vacas leiteiras suplementadas com ionóforos. Diversos estudos têm citado nenhum efeito ou pequenas diminuições no consumo (SAUER et al., 1989). No entanto, novos estudos de Symanowski et al. (1999) tem sugerido que o consumo de matéria seca é levemente diminuído $(<1$ $\mathrm{kg} / \mathrm{dia})$.

Os aumentos na produção de propionato e da gliconeogênese resultariam em melhor aproveitamento de aminoácidos e diminuição da lipogênese, através da diminuição da mobilização de gordura do tecido adiposo resultando em menores níveis de corpos cetônicos no fígado. Duffield et al. (1998a, 1998b, 1999) demonstraram o potencial de administração de monensina através de cápsulas de liberação lenta (335 mg/dia de monensina por 95 dias) para vacas no pré-parto. Em um experimento que contou com mais de 1000 vacas e novilhas estes autores observaram redução nas concentrações de betahidroxibutirato (BHBA) e aumento nas concentrações de glicose e uréia plasmática com a administração do ionóforo. Estes animais também apresentaram menor perda de escore de condição corporal, mostrando que a monensina pode ser uma importante ferramenta no controle do status energético de vacas recém-paridas (DUFFIELD et al., 1998a).

Estudos têm sido conduzidos com objetivo de mensurar a existência de resíduos de monensina sódica no leite ou na carne de ruminantes. Segundo a Food and Agriculture Organization of the United Nations/World Health Organization (FAO/WHO) através do Codex Alimentarius Commission (2009), o limite máximo para a presença de monensina sódica no leite é da ordem de $2 \mu \mathrm{g} / \mathrm{kg}$ ou de $2 \mathrm{ppb}$. Para a carne bovina esse valor está em 
torno de 10 ppb, e sendo o fígado órgão de eleição para detecção de resíduos de monensina, limite máximo é de 20 ppb.

A utilização da monensina sódica para vacas leiteiras não traz qualquer risco a saúde humana, e os resíduos quando detectados são observados em valores baixos, mesmo com doses muito elevadas do ionóforo e, além disso, estes resultados são obtidos em condições experimentais extremas, que geralmente não são utilizados em rações em sistemas de produção leiteira. O mecanismo de ação dos ionóforos pode resultar em alterações coordenadas no metabolismo dos animais que podem maximizar as respostas produtivas e melhorar o nível metabólico dos animais. Os ionóforos devem ser largamente explorados, sempre levando em consideração fatores como a dose utilizada, a forma de administração, volumoso utilizado, fase de lactação e nível de produção dos animais, para sua correta utilização em diferentes situações de produção. 


\section{HIPÓTESE E OBJETIVOS}

Como hipótese científica deste trabalho foi proposto que a monensina sódica utilizada em dose adequada melhoria e desempenho produtivo de vacas leiteiras no terço médio de lactação, sem deixar resíduos prejudiciais à saúde humana no leite.

O presente estudo foi conduzido com o objetivo de avaliar os efeitos de diferentes concentrações de monensina sódica adicionada às rações de vacas em lactação sobre o consumo e digestibilidade aparente total da matéria seca e nutrientes, fermentação e síntese de proteína microbiana ruminal, produção e composição do leite, concentrações de parâmetros sanguíneos, balanço de energia e de nitrogênio e resíduos de monensina no leite. 


\section{REVISÃO DE LITERATURA}

\subsection{IONÓFOROS NA ALIMENTAÇÃO DE RUMINANTES}

Os ionóforos são assim chamados em função da sua propriedade transportadora de íns, possuindo capacidade de formar complexos lipossolúveis com cátions e mediar seu transporte através das membranas lipídicas (PRESSMAN, 1968).

Ionóforos, como a monensina sódica, são compostos produzidos por bactérias, sobretudo do grupo Streptomyces cinnamonensis, que, sendo altamente lipofílicos e tóxicos a muitos microrganismos, são definidos como antibióticos (HANEY ; HOEHN, 1967). Existem mais de 70 tipos diferentes de ionóforos, como a monensina, lasolocida, salinomicina, narasina, tetronasina, lisocelina, dianemicim, nigercim, gramicidim e laidlomicina.

No Brasil, a monensina sódica tem seu uso liberado para ser incluído em dietas para ruminantes em crescimento, terminação e vacas lactantes (OLIVEIRA et al., 2005).

O motivo de estes ionóforos aumentarem o desempenho de animais é atribuído principalmente à melhora da eficiência energética devido ao aumento da digestibilidade dos alimentos, ao aumento da produção do ácido propiônico, redução da relação de acetato/propionato, diminuição da produção de metano, diminuição da produção de ácido láctico, e por reduzir as perdas de proteína e aminoácidos que seriam potencialmente fermentados em nível de rúmen, para a produção de amônia (RUSSELL ; STROBEL, 1989). 
O modo de ação da monensina sódica é a mudança no movimento de íons através de membranas, alterando o gradiente de prótons e, consequentemente, o $\mathrm{pH}$ dentro da célula. Desta forma, este gasto de energia pode levar a redução no crescimento, reprodução e, muitas vezes, até a morte de determinado tipo de bactéria (McGUFFEY et al., 2001).

Em um estudo realizado por Schelling (1984), foi proposto sete modos de ação, através dos quais, monensina, melhora o desempenho de ruminantes: 1) modificação na produção de ácidos graxos voláteis, 2) alteração no consumo de alimentos, 3) alteração na produção de gases, 4) modificação na digestibilidade dos alimentos, 5) alteração no enchimento do rúmen e taxa de passagem, 6) alteração na utilização de proteína e 7) outros modos de ação.

A monensina quando adicionada na alimentação de bubalinos apresenta redução na produção de metano (BARMAN et al., 2001) e de amônia e na população de protozoários, além de ocasionar aumento na produção de propionato ruminal (BADWAY et al., 1996).

Hergazy (1997) constatou que búfalas leiteiras suplementadas com monensina apresentaram melhor escore de condição corporal na parição e na próxima concepção, indicando que a monensina pode ser um aditivo vantajoso na produção de bubalinos.

Vários ionóforos (monensina, lasalocida, salinomicina, nasarina) tem sido fornecidos a bovinos de corte, sendo a eficácia desses compostos considerada similar. Nas dietas que contém níveis elevados de carboidratos rapidamente fermentáveis, os ionóforos geralmente deprimem o consumo de alimento, porém o ganho de peso não é diminuído e a conversão alimentar é melhorada. Quando bovinos são alimentados com dietas contendo consideráveis quantidades de forragem, os ionóforos não reduzem o consumo, a conversão alimentar é aumentada, porém, com aumento do ganho de peso (NAGAJARA et al., 1981).

Chalupa (1977), em revisão de uma série de experimentos sobre os efeitos da monensina no desempenho de bovinos, observou que, nos estudos de confinamento, animais 
que receberam monensina (5,5 a $33 \mathrm{mg}$ de monensina/ $\mathrm{Kg}$ de alimento ofertado) consumiram menos alimentos, mas mantiveram o ganho de peso e que essas reduções geralmente foram maiores durante as quatro primeiras semanas após o fornecimento de monensina. Em animais mantidos em pastagem ou receberam forragem verde picada no cocho, a adição de 50 a $300 \mathrm{mg}$ monensina/dia ocasionou aumento de cerca de $20 \%$ no ganho de peso. Nesses ensaios, independentemente do regime alimentar, a eficiência alimentar também melhorou.

Segundo Russell e Strobel (1989), quando a monensina liga-se à membrana celular, a primeira reação que ocorre é a rápida saída de $\mathrm{K}+$ e uma entrada de $\mathrm{H}+$ na célula, provocada pela mudança do gradiente iônico externo. $\mathrm{O} \mathrm{H}+$ acumulado no interior da célula ocasiona diminuição do $\mathrm{pH}$. A célula responde a esta queda no $\mathrm{pH}$ exportando $\mathrm{H}+$ para fora e permitindo a entrada de $\mathrm{Na}+$ para o interior da célula. A segunda reação se caracteriza pelo transporte de $\mathrm{Na}+$ para dentro e de $\mathrm{H}+$ para fora da célula, embora esta seja menos eficiente que a primeira reação.

Outra forma de exportar o $\mathrm{H}+$ é por meio da bomba de próton ATPase. Assim, grande parte da energia produzida pela célula é utilizada pelas bombas de $\mathrm{Na}+\mathrm{K}+$ e de próton ATPase, na tentativa de manter o pH e o balanço iônico celular. Com o passar do tempo, a célula se torna incapaz de continuar metabolizando a glicose, diminuindo a capacidade de crescimento e de reprodução das bactérias, que acabam morrendo ou assumem um nicho microbiano sem expressão ruminal (RUSSELL ; STROBEL, 1989).

A utilização de ionóforos modifica o movimento de íons através da membrana das bactérias, pela ligação do íon metálico $(\mathrm{Na}+)$ presente no centro da sua molécula à membrana da bactéria, com isso há uma saída de íons potássio da célula e entrada de íons hidrogênio. Para a manutenção do equilíbrio da célula os íons hidrogênio devem ser expulsos por transporte ativo envolvendo gasto de energia resultando na morte ou redução 
do crescimento da célula. As bactérias gram negativas apresentam em sua membrana rígida camada de peptideoglicano, servindo como uma barreira para a penetração da monensina no interior da célula. Já as bactérias gram positivas não possuem a camada de peptidioglicano por esse motivo são sensíveis à ação dos ionóforos (BERGEN ; BATES, 1984).

Oelker et al. (2009) avaliaram dois tipos de volumosos, feno de alfafa e silagem de milho para vacas no terço médio de lactação, e com suplementação de $17 \mathrm{mg} / \mathrm{kg}$ MS de monensina e observaram diferença $(\mathrm{P}<0,05)$ para produção de leite $(38,4 \mathrm{vs} 34,5 \mathrm{~kg} / \mathrm{dia})$ e digestibilidade da matéria seca $(70,0$ vs $64,6 \%$ ), quando comparadas ao controle. No entanto, não observaram diferença no consumo de matéria seca $(21,7$ vs 20,6 kg/dia), respectivamente, para silagem de milho e feno de alfafa.

Baseado no potencial da monensina em aumentar a provisão de precursores glicogênicos, diversos, autores sugeriram o uso da monensina em vacas no período de transição, onde a administração de monensina para vacas neste período da lactação pode aumentar a síntese hepática de glicose e, então, melhorar o balanço de energia em vacas neste período .

Após avaliarem 13 estudos compilados, Ipharraguerre e Clark (2003), observaram somente que em quatro deles houve aumento significativo na concentração da glicose plasmática, além disso, nestes estudos o aumento na disponibilidade deste metabólico foi relativamente pequeno $(5,9 \%)$. A resposta para administração de monensina foi significativa quando foram suplementadas vacas com doses que variavam de 16 a $17 \mathrm{mg} / \mathrm{kg} \mathrm{MS}$, com período de pelo menos seis semanas pré-parto ou dentro das primeiras duas semanas de lactação.

A hipótese de que a monensina pode melhorar a saúde e a fertilidade tem sido bastante investigada aleatoriamente em estudos clínicos controlados (LEAN et al., 1994; BECKETT et al., 1998; HEUER et al., 2001; DUFFIELD et al., 2002). Alguns estudos observaram um 
menor risco de deslocamento abomasal (DUFFIELD et al., 2002) e outros uma redução no risco de mastite (HEUER et al., 2001). Outros estudos não identificaram benefícios significantes à saúde (BECKETT et al., 1998).

Apesar de vários estudos sendo conduzidos e uma substancial confirmação dos efeitos positivos da monensina no metabolismo energético (DUFFIELD et al., 2008), nenhum benefício reprodutivo da monensina tem sido reportado (LEAN et al., 1994; HAYES et al., 1996; DUFFIELD et al., 1999; HEUER et al., 2001); uma meta-análise prévia dos grandes e precoces estudos indicaram que havia uma pequena prospecção de um efeito significante da monensina na performance reprodutiva (LEAN; WADE, 1997).

O impacto da monensina na redução da mastite de $9 \%$ é um pequeno efeito, mas um resultado interessante. Reduções na incidência de mastite com tratamento de monensina (HEUER et al., 2001) e para tratamento lasalocida (McDOUGALL et al., 2004) tem sido previamente descrito. O mecanismo mais provável para isso é o metabolismo energético ser superior, melhorando a função imune e permitindo a vaca melhor organizar uma forte defesa contra o desafio das infecções.

Stephenson et al. (1997) sugere que a superioridade na absorção dos cations bivalentes com o tratamento da monensina poderia também influenciar nas respostas a doenças, porque esses cations são importantes nos mecanismos anti-oxidantes e nos mecanismos de defesa dos neutrófilos e macrófagos. Monensina tem sido demonstrada para melhorar quimiotaxia dos neutrófilos, e elevações nas concentrações de betahidroxibutirato (BHBA) e ácidos graxos não esterificados (NEFA) tem sido associada com função imune afetada (SURIYASATHAPORN et al., 2000; LACETERA et al., 2004). 


\subsection{MONENSINA SÓDICA NA ALIMENTAÇÃO DE VACAS LEITEIRAS}

Os ionóforos são aditivos não nutricionais, com capacidade de manipular a fermentação ruminal. A monensina sódica é um ionóforo, produzido por cepa de Streptomyces cinnamonensis (DUFFIELD ; BAGG, 2000).

Van der Merwe et. al. (2001) em experimento realizado com vacas holandesas no início de lactação criadas à pasto, observaram que o grupo tratado com $300 \mathrm{mg}$ monensina/vaca/dia, apresentou melhor escore de condição corporal que o grupo controle. Vacas em início de lactação alimentadas com $300 \mathrm{mg}$ de monensina/dia, apresentam redução na ingestão de alimento sem diminuir a produção de leite, gordura corrigida e ainda diminui a perda de peso normal do pós parto (SAUER et al., 1989). Campos Neto et al. (1995) constataram que a adição de 300 mg monensina sódica na alimentação de bovinos leiteiros em início de lactação, aumentou a produção de leite em $13,5 \%$ com redução no consumo de ração total.

De acordo com o estudo de Van Der Werf et al. (1998), vacas Holandesas e Jersey tratados com monensina apresentaram maiores escore de condição corporal e ganho de peso no final da lactação pela melhor utillização do alimento, além disso observaram aumento da produção total de leite, produção de proteína $(5,9 \%)$ e gordura $(3 \%)$, tendo somente uma redução na produção de gordura quando as vacas foram alimentadas com doses altas do ionóforo (450 mg/cab/dia).

Ruiz et al. (2001), utilizaram a monensina na alimentação de vacas Holandesas, com alimentação à base de forragem fresca e observaram aumento de $6,5 \%$ na produção de leite, $4,6 \%$ na produção de gordura e $4,7 \%$ na produção de proteína, porém uma redução de 0,12 unidades percentuais na porcentagem de gordura. Resultados semelhantes foram 
encontrados por Hayes et al. (1996), quando avaliaram o efeito da monensina em vacas alimentadas a pasto. $\mathrm{O}$ grupo suplementado com monensina apresentou produção de 1,38 litros de leite/dia a mais que o grupo controle, aumento na produção de proteína de 0,03 $\mathrm{Kg} /$ dia e $0,02 \mathrm{Kg} /$ dia na produção de gordura, sendo estas diferenças somente significativas para a produção de leite.

Entretanto, Vallimont et al. (2001) não observaram diferenças significativas para a produção de leite quando vacas no início da lactação foram suplementadas com monensina sódica mesmo o tratamento com monensina sendo numericamente superior ao controle.

O período de lactação dos animais é o fator que tem maior influência sobre a resposta a suplementação com monensina sódica em vacas leiteiras. Segundo Ipharraguerre e Clark (2003) a monensina aumenta as concentrações plasmáticas de glicose e reduz a quantidade no plasma de ácidos graxos não-esterificados e de corpos cetônicos, que estão associados à redução no consumo no início da lactação.

Baseado no potencial da monensina em aumentar a provisão de precursores glicogênicos, diversos autores sugeriram o uso da monensina em vacas no período de transição, onde a administração de monensina para vacas neste período da lactação pode aumentar a síntese hepática de glicose e, então, melhorar o balanço de energia em vacas neste período (GANDRA et al., 2009).

Duffield et al. (2008) avaliaram os efeitos da monensina no metabolismo de vacas leiteiras e constataram que esse ionóforo aumenta em aproximadamente $3,0 \%$ os níveis de glicose e em $6,0 \%$ os níveis de uréia circulantes, mas não observaram efeito nas concentrações de colesterol total. O aumento na concentração plasmática de glicose está relacionado ao aumento de propionato que chega ao fígado, em decorrência da mudança do perfil fermentativo ruminal da monensina (MARTINEAU et al., 2007). 
Pesquisas que envolvem monensina sódica para vacas em lactação têm produzido resultados divergentes, indicando haver interações entre fatores dietéticos e fisiológicos envolvidos (IPHARRAGUERRE ; CLARK, 2003). Fatores como o volumoso utilizado, o período de lactação, o nível de produção e a dose utilizada de monensina sódica interagem e geram resultados muitas vezes contraditórios nos estudos. Desta forma, para haver correta avaliação de resultados a respeito deste ionóforo, deve se considerar todos esses aspectos muito bem definidos.

Segundo McGuffey et al. (2001), Ipharraguerre e Clark (2003) e Duffield et al. (2008), a dose de monensina sódica para vacas leiteiras em qualquer período de lactação ou submetidas a qualquer tipo de volumoso pode ser definida de duas formas, $16 \mathrm{mg} / \mathrm{kg} \mathrm{MS} \mathrm{ou}$ $24 \mathrm{mg} / \mathrm{kg}$ MS, sendo esta última forma utilizada para animais em produção, e a primeira em animais em crescimento ou em período de transição. Doses superiores a estas não são recomendadas, pois podem causar queda no desempenho produtivo dos animais ou até mesmo intoxicações (PLAZIER et al., 2000).

\subsubsection{Consumo de Matéria Seca}

O consumo de matéria seca é determinado pelo conjunto de informações e sinais enviados ao centro da saciedade do sistema nervoso central. O propionato apresenta efeito supressor sobre o consumo, uma vez que estimula a síntese e liberação de insulina no sangue, ressaltando que os hepatócitos de ruminantes apresentam alta atividade de propionil-Coa sintetase e baixa de acetil-COA sintetase, o que poderia explicar a falta de resposta no consumo quando acetato foi infundido no sistema porta. No entanto, a 
modificação dos produtos finais da fermentação ruminal nas dietas com monensina sódica, com aumento da proporção molar de propionato, pode ser suficiente para determinar a redução do consumo (ALLEN, 2000).

O consumo de matéria seca geralmente é muito variável em vacas leiteiras suplementadas com monensina. Em relação aos efeitos da monensina, alguns trabalhos observaram diminuição do consumo, como os estudos de Sauer et al. (1989) e Green et al. (1999). Nenhum efeito no consumo de matéria seca foi relatado na grande maioria dos estudos, como Bell et al. (2006), Da Silva et al. (2008), Erasmus et al. (2008) e Oelker et al. (2009). Ipharraguerre e Clark (2003) reportaram que de 12 experimentos avaliados, somente em quatro foram observados redução no consumo de matéria seca de vacas leiteiras.

A variação no consumo está altamente correlacionada com o período de lactação e a dose do ionóforo utilizado. Vacas em período de transição e no início de lactação não sofrem influência da utilização da monensina sódica sobre o consumo de matéria seca em suas dietas (DUFFIELD et al., 2008). Segundo McGuffey et al. (2001) e Ipharraguerre e Clark (2003), vacas no terço médio e final de lactação tem redução do consumo de matéria seca semelhante a bovinos de corte.

Segundo Gandra et al. (2009), a utilização de monensina sódica nas rações ocasionou redução do consumo de matéria seca, que em média, reduziu 2,94\% e 12,42\% nas rações com 24 e $48 \mathrm{mg} / \mathrm{kg}$ de monensina sódica, respectivamente, em relação à ração controle. Symanowski et al. (1999) utilizaram monensina na concentração de 0, 8, 16 e $24 \mathrm{mg} / \mathrm{Kg} \mathrm{MS}$ e observaram redução de consumo nos níveis de 16 e $24 \mathrm{mg} / \mathrm{Kg} \mathrm{MS}$. De forma similar, McClary et al. (2005) avaliaram diversas doses de monesina (0, 7, 15 e $22 \mathrm{mg} / \mathrm{Kg} \mathrm{MS})$ para vacas leiteiras e observaram que nos dois maiores níveis, houve redução de consumo.

A utilização de 16 a $24 \mathrm{mg} / \mathrm{kg}$ MS de monensina sódica nas rações de vacas leiteiras no terço inicial a médio de lactação parece ser o limite de fornecimento onde pode haver 
alguma alteração no consumo. Doses acima de $35 \mathrm{mg} / \mathrm{kg}$ MS de monensina poderiam estar relacionadas a forte redução de consumo em vacas no terço inicial a médio da lactação.

\subsubsection{Digestibilidade Aparente Total}

A digestibilidade aparente total da matéria seca e dos nutrientes está intimamente relacionada a eventos ruminais quanto a $\mathrm{pH}$, taxa de passagem e degrabilidade dos alimentos pelos microrganismos do rúmen (NRC, 2001). A monensina sódica como potente modulador da fermentação ruminal pode de certa forma alterar a digestibilidade de alguns nutrientes pela modulação do $\mathrm{pH}$ ruminal e pela mudança que os microrganismos ruminais sofrem com a suplementação do ionóforo (DUFFIELD \& BAGG, 2000).

A monensina sódica pode influenciar na digestibilidade aparente total da proteína e da fibra, e o mecanismo fisiológico que leva a alteração em ambas não está totalmente elucidado devido a grande discrepância entre os resultados da literatura (BENCHAAR et al., 2006). Esses resultados de digestibilidade são fruto de inúmeras interações que a monensina pode sofrer em rações para vacas leiteiras, como o tipo do volumoso utilizado, nível de produção dos animais, dose do ionóforo utilizado e o período de lactação, que podem influenciar os resultados de digestibilidade da matéria seca e dos nutrientes (OSBORNE et al., 2004).

Segundo Gandra (2009), em experimento com vacas Holandesas em terço médio de lactação, suplementadas com monensina sódica nas concentrações de 0,24 e $48 \mathrm{mg} / \mathrm{Kg}$ de MS, não foi observado efeito na excreção total de fezes, na digestibilidade aparente total da matéria seca, matéria orgânica, proteína bruta, extrato etéreo, fibra em detergente neutro, 
carboidratos não fibrosos carboidratos totais, e nos valores de nutrientes digestíveis totais observados para as rações experimentais.

Resultados de pesquisas refletem dados inconsistentes sobre o efeito da monensina sódica sobre a digestibilidade aparente total da matéria seca e dos nutrientes em vacas em lactação. Alguns estudos mostram aumento na digestibilidade da fibra (SPEARS, 1990; OSBORNE et al. 2004). Este efeito pode estar relacionado ao aumento de $\mathrm{pH}$ promovido pela suplementação de monensina, que desta forma poderia proporcionar melhor digestão da fibra (VARGA, 1997).

Osborne et al. (2004) suplementaram vacas no teço médio de lactação com 22 mg/kg MS de monensina, sendo a silagem de milho o volumoso basal, e observaram aumento de 16,4\% na digestibilidade da FDN e de $14,3 \%$ na de FDA, quando comparado à ração controle.

Benchaar et al. (2006) realizaram estudo onde suplementaram vacas no início da lactação com 16 mg/kg MS de monensina sódica, tendo como volumosos silagem de milho (12\%) e silagem de capim (37\%), e observaram aumento da digestibilidade aparente total da proteína de 2 pontos percentuais em relação ao controle.

Plazier et al. (2000) reportaram aumento na digestibilidade da proteína quando suplementaram vacas leiteiras no início da lactação. Da Silva et al. (2008), Gehman et al. (2008) e Oelker et al. (2009) não observaram efeito da utilização da monensina sobre a digestibilidade da proteína em vacas no mesmo período de lactação. Discrepâncias entre estudos podem estar relacionadas à composição da dieta basal. De acordo com Plazier et al. (2000) a monensina sódica aumenta a digestibilidade aparente total da proteína em rações com altas concentrações de forragens. 


\subsubsection{Fermentação Ruminal}

Estudos têm demonstrado que a monensina sódica atua selecionando determinadas cepas de bactérias podendo levar a mudanças no processo de fermentação ruminal (BERGEN ; BATES, 1984; RUSSELL, 1988). A presença da monensina também pode favorecer o crescimento de certas bactérias em relação a outras, assim o metabolismo da bactéria beneficiada pode afetar o desempenho do animal hospedeiro e proporcionar vantagens nutricionais ou metabólicas em relação ao animal não suplementado (DUFFIELD ; BAGG, 2000).

As diferenças estruturais entre bactérias gram-positivas e gram-negativas estão envolvidas neste processo de seleção. Bactérias gram-negativas contém complexa parede celular que atuam como barreira para a ação da monensina, tornando-se mais resistentes. Também, diferenças no complexo enzimático conferem maior sobrevivência na presença da monensina a estas bactérias. Bactérias gram-positivas não possuem esta membrana externa, estando susceptíveis as ações do ionóforo (McGUFFEY et al., 2001; IPHARRAGUERRE ; CLARK, 2003).

A bactéria Megasphaera elsdenii é espécie utilizadora primária de lactato no rúmen, e Selenomonas ruminantium é espécie utilizadora menos ativa, mas essas são resistentes à monensina (NAGAJARA et al. 1981). As diferenças de sensibilidade a monensina das bactérias produtoras e utilizadoras de lactato, podem ser explicadas pelo declínio do lactato ruminal in vivo e elevações nos valores do $\mathrm{pH}$.

Desta forma, a utilização da monensina em dietas de vacas leiteiras faz com que a proporção de bactérias gram-negativas aumente em nível ruminal, enquanto as bactérias gram-positivas estariam diminuídas. Assim, podem ocorrer modificações em relação aos 
produtos resultantes da fermentação (NRC, 2001). A alteração da população microbiana no rúmen leva às mudanças no processo de fermentação ruminal, já que bactérias gramnegativas tem o succinato como produto final da fermentação.

Assim, a monensina seleciona comunidade bacteriana que produz mais propionato e menos lactato, acetato e butirato, e indiretamente, menos metano (bactérias metanogênicas) e gás carbônico (THORNTON ; OWENS, 1981; SPEARS, 1990). Segundo Russell e Strobel (1989), a monensina inibe as bactérias produtoras de hidrogênio, formato, acetato, butirato, lactato e amônia, enquanto que as produtoras de succinato, propionato e as utilizadoras de lactato são resistentes.

O principal benefício de serem suplementadas vacas leiteiras com monensina sódica é o potencial da troca na relação acetato/propionato, com maior produção de propionato e diminuição da metanogênese. Sauer et al. (1998) trabalharam com vacas no terço médio de lactação, recebendo silagem de milho e com dose de $24 \mathrm{mg} / \mathrm{kg}$ MS de monensina sódica, numa proporção de concentrado e volumoso de 35:65, e observaram decréscimo na relação acetato/propionato, observando aumento na concentração molar de propionato de $17 \%$.

Em estudo realizado por Broderick (2004), com vacas no início de lactação com produção média de leite de $35 \mathrm{~kg} /$ dia, recebendo silagem de alfafa e suplementadas com 10 mg/kg MS de monensina sódica nas rações, foi observado aumento da concentração molar de propionato em $10 \%$, diminuição da relação acetato/propionato em $15 \%$ e diminuição da concentração molar de acetato em $3 \%$, quando a ração com monensina foi comparada a controle.

De modo semelhante Eifert et al. (2005) suplementaram vacas no inicio da lactação com $16 \mathrm{mg} / \mathrm{kg}$ MS de monensina e recebendo silagem de milho, e observaram aumento da porcentagem de propionato de $17 \%$, diminuição da porcentagem de acetato de $6 \%$ e diminuição de $21 \%$ na relação acetato/propionato, quando comparou as rações com 
monensina ao controle. Grazin et al. (2005) suplementaram vacas leiteiras no terço médio de lactação com $20 \mathrm{mg} / \mathrm{kg}$ MS de monensina e recebendo pastagem mista de gramíneas e leguminosas, e observaram aumento de $9 \%$ na porcentagem de propionato e diminuição de $13 \%$ na relação acetato/propionato quando compararam a ração com monensina ao controle, porém não observaram efeito da suplementação de monensina em relação à concentração de acetato.

No entanto, Martineau et al. (2007) quando suplementaram vacas com $24 \mathrm{mg} / \mathrm{kg} \mathrm{MS}$ de monensina, utilizando silagem de leguminosas, não observaram efeito sobre as concentrações de acetato e propionato ao compararem a ração com monensina à controle, porém observaram diminuição de $10 \%$ na relação acetato/propionato em relação ao controle.

Segundo Gandra (2009), em experimento suplementando vacas leiteiras com monensina sódica nas concentrações de 0,24 e $48 \mathrm{mg} / \mathrm{Kg}$ de $\mathrm{MS}$, houve redução na porcentagem e concentração molar dos ácidos acético e butírico, bem como para a relação acetato/propionato. Foi observado desvio da linearidade para a porcentagem e concentração molar do ácido propiônico, sendo as maiores concentrações encontradas para a ração M24. Comportamento semelhante foi observado para a concentração total de ácidos graxos de cadeia curta. Estes resultados obtidos estão relacionados com a mudança causada pela monensina sódica nas populações de microrganismos do rúmen, que privilegia os microorganismos produtores de propionato, resultando também em redução de metano e melhor eficiência de utilização de energia no ambiente ruminal.

Outro efeito benéfico da utilização de monensina em rações de vacas leiteiras pode estar associado ao pH ruminal. Em situações onde os animais são alimentados com dietas à base de forragens, o pH fica próximo da neutralidade, mas, com o fornecimento de rações com alta quantidade de grãos, que torna a dieta altamente fermentável, o $\mathrm{pH}$ pode diminuir drasticamente dado o acúmulo de lactato no fluído ruminal (SLYTER, 1976). Desta forma, 
a monensina é capaz de diminuir a produção de ácido lático e os animais tem menor concentração de lactato e maiores valores de pH de rúmen (NAGAJARA et al., 1981).

A redução da degradação da proteína no rúmen poderia auxiliar a explicar o melhor desempenho dos animais que consomem dietas com ionóforos, já que as populações de bactérias com alta capacidade de fermentação de aminoácidos estariam eliminadas ou diminuídas (RUSSELL, 1988; CHEN ; RUSSELL, 1989). A monensina é capaz de diminuir a produção de amônia in vitro e in vivo (VAN NEVEL ; DEMEYER, 1977), e esse decréscimo, provavelmente, é responsável por efeito chamado "protein-sparing”, ou seja, efeito de aumento de proteína disponível para o animal. O uso de ionóforos diminui o crescimento de bactérias proteolíticas (HINO ; RUSSELL, 1986) e também inibe a degradação de proteína hidrolisada tão bem quanto de proteína da dieta (RUSSELL ; MARTIN, 1984). A deaminação é mais afetada pela ação dos ionóforos do que a proteólise.

Russell (1996) verificou o efeito da monensina sobre a concentração de amônia no rúmen, a atividade específica de produção de amônia e o provável número de aminoácidos e carboidratos fermentado pelas bactérias do rúmen. Os bovinos foram alimentados com forragem 12 vezes por dia, de modo que a concentração de amônia atingiu seu estado de estabilidade. A monensina proporcionou redução de 50\% na concentração de amônia ruminal, a atividade específica da mistura microbiana também foi diminuída, bem como redução de quase 10 vezes nos aminoácidos fermentados. Essas diminuições, no entanto, são dependentes da quantidade de proteína e carboidratos degradáveis no rúmen, e se caso a dieta utilizada possui alta concentração de amido, a amônia ruminal poderá ser naturalmente baixa e a utilização de monensina não terá muito efeito. Portanto, a ação da monensina sobre a diminuição da amônia ruminal é verificada com mais eficácia nas dietas com maior proporção de forragem, já que nessas condições, a taxa de proteína degradada excede a taxa de carboidratos fermentados, e o nível de amônia ruminal são geralmente altos. 
O decréscimo de amônia ruminal vai depender da taxa de proteína degradável no rúmen e do nível de amido na dieta, pois, em baixos níveis, a produção de amônia ruminal é baixa e a ação da monensina não apresenta efeitos. Esses efeitos são mais drásticos em dietas a base de forragem, pois, sob estas condições, a taxa de degradação de proteína é muito maior que a taxa de fermentação de carboidratos e os níveis de amônia ruminal geralmente são altos (RUSSELL, 1996). Segundo Chen e Russell (1989) e Krause e Russell (1996), a monensina reduz a produção de amônia tanto in vitro quanto in vivo, respectivamente. No entanto, não foi verificado o efeito da monensina sobre diferentes fontes de alimento.

No estudo de Benchaar et al. (2006) foram suplementadas vacas no terço inicial de lactação com dose de monensina de $16 \mathrm{mg} / \mathrm{kg} \mathrm{MS}$, tendo como volumoso a silagem de milho, e foi observado decréscimo de $11,8 \%$ nos níveis de amônia ruminal em relação ao controle. No entanto, Eifert et al. (2005); Gehman et al. (2008) e Oelker et al. (2009), que também avaliaram vacas leiteiras no terço inicial e médio de lactação, e doses de 16 a 22 $\mathrm{mg} / \mathrm{kg}$ MS de monensina, tendo a silagem de milho como volumoso, não observaram efeito da monensina sódica sobre a concentração de amônia ruminal. Resultados mais recentes envolvendo o metabolismo de nitrogênio amoniacal sobre a suplementação de monensina mostram que parece haver interação com a dose utilizada, período de lactação e nível de produção dos animais. 


\subsubsection{Síntese de Proteína Microbiana}

Na nutrição protéica de ruminantes, é fundamental a estimativa acurada da síntese de proteína microbiana ruminal e de sua contribuição em aminoácidos digestíveis para o animal. Estratégias de alimentação que alteram a produção de proteína microbiana afetam a quantidade e a qualidade da proteína que chega ao intestino delgado (MOSCARDINI et al., 1998).

O fluxo de nitrogênio $(\mathrm{N})$ microbiano para o duodeno pode ser estimado a partir da excreção urinária de derivados de purina (principalmente alantoína e ácido úrico), sendo que a quantidade de ácido nucléico microbiano e, conseqüentemente, a síntese microbiana ruminal são proximamente correlacionadas à excreção urinária de derivados de purina (MOSCARDINI et al., 1998). González-Ronquillo et al. (2004) demonstraram a utilidade dos derivados de purina urinários como potencial meio de detecção de alterações na síntese microbiana ruminal, e com a mesma eficiência do método baseado na medição do fluxo duodenal pela técnica de dois indicadores.

A influência da suplementação de monensina sódica na síntese de proteína microbiana e nos derivados de purinas em vacas leiteiras está relacionada com o metabolismo de nitrogênio ruminal. Como a monensina tem a característica de diminuir a deaminação ruminal e as concentrações de nitrogênio amoniacal, fisiologicamente admite-se que haja diminuição da síntese de proteína microbiana e que ocorra aumento do escape de proteína do rúmen. Em relação à eficiência da produção da proteína microbiana especula-se que haja melhoria, especialmente quando a monensina tenha efeito negativo no consumo de matéria seca (GANDRA et al., 2009). 
Em estudos recentes que avaliaram a eficiência de síntese de proteína microbiana em vacas leiteiras suplementadas com monensina, os resultados ainda são muito controversos. Eifert et al. (2005) avaliaram a suplementação de monensina na dose de $16 \mathrm{mg} / \mathrm{kg} \mathrm{MS}$ em vacas leiteiras no início da lactação, tendo como volumoso à silagem de milho, e observaram diminuição de 7\% na síntese de proteína microbiana em relação ao controle, porém não encontrou efeito algum sobre a eficiência de produção de proteína microbiana. Contrariamente, Gehman et al. (2008) utilizaram vacas no terço médio de lactação e com dose de $16 \mathrm{mg} / \mathrm{kg} \mathrm{MS}$, com o mesmo volumoso, e não observaram nenhum efeito sobre a síntese ou eficiência de produção da proteína microbiana.

A síntese de proteína microbiana em vacas leiteiras suplementadas com monensina sódica parece estar intimamente ligada ao consumo de matéria seca e a dose de monensina empregada. Porém, a falta de estudos envolvendo a ação deste ionóforo sobre a eficiência e síntese de proteína microbiana, não permite extrair da literatura dados conclusivos e coesos. Dentro deste cenário, é preciso intensificar as pesquisas a este respeito para que se possam inferir afirmações concretas.

\subsubsection{Produção e Composição do Leite}

A melhora na produção de leite mediante a suplementação de monensina sódica está intimamente relacionada ao mecanismo de ação do ionóforo no ambiente ruminal. $\mathrm{O}$ aumento da concentração molar de propionato aumenta o fluxo de glicogênio hepático, contribuindo com o aumento na produção (OBA ; ALLEN, 2003). Da mesma forma, alterações na composição do leite também se relacionam com seu mecanismo de ação, 
porém estão também relacionados com interações que a monensina estabelece com o estágio de lactação, tipo de volumoso e nível de produção dos animais (DUBUC et al., 2009). Assim, a influencia que a monensina sódica exerce sobre a eficiência produtiva em vacas de leite se relaciona com o consumo de matéria seca, nível de produção e estágio de lactação.

De acordo com Ruiz et al. (2001), que utilizaram a monesina na alimentação de vacas Holandesas, em dieta à base de forragem fresca, e observaram aumento de 6,5\% na produção de leite, 4,6\% na produção de gordura e 4,7\% na produção de proteína, havendo, porém, redução de 0,12 unidades percentuais na porcentagem de gordura.

Resultados semelhantes foram encontrados por Hayes et. al. (1996), ao avaliarem o efeito de monensina em vacas em pastejo. A suplementação com monensina provocou aumento nas produções de leite (1,38 litros de leite/animal/dia), mas essas diferenças foram significativas somente para produção de leite.

Gandra (2009) observou que vacas suplementadas com $24 \mathrm{mg} / \mathrm{Kg}$ de $\mathrm{MS}$ apresentaram aumento na produção de leite, com e sem correção, e produção de gordura e lactose. A utilização de monensina sódica na ração no nível de 24 mg/kg MS resultou em melhor desempenho do que as vacas submetidas à ração controle, produzindo em média mais $0,66 \mathrm{~kg} /$ dia ou $2,7 \%$ de leite. Como houve menor consumo e maior produção de leite para esta ração contendo monensina sódica, foi observado aumento da eficiência produtiva.

Entretanto, Vallimont et al. (2001) não observaram diferenças na produção de leite quando vacas, no início de lactação, foram suplementadas com monensina sódica. Resultados similares foram encontrados por Ramanzin et al. (1997), quando pesquisaram o efeito da monensina em vacas consumindo dietas contendo relação volumoso:concentrado de 70:30.

Segundo Campos Neto et al. (1995), verificaram que mesmo com redução do consumo da ração, houve aumento significativo na produção de leite para as vacas alimentadas com 
$300 \mathrm{mg} / \mathrm{cab} /$ dia, a qual esta está diretamente associada a utilização da energia metabolizável, proporcionado pelo aumento da proporção molar do ácido propiônico a nível de rúmen que sendo precursor direto da formação de glicose, atua diretamente na galactopoiese a nível de glândula mamária.

Interações dos níveis de carboidratos não fibrosos e a fibra fisicamente efetiva foram reportados influenciando a porcentagem de gordura no leite em vacas suplementadas com monensina. Dubuc et al. (2009) avaliaram mais de 47 rebanhos leiteiros, e utilizaram dose de $16 \mathrm{mg} / \mathrm{kg}$ MS de monensina nas rações, e mensuraram a gordura do leite direto dos tanques de resfriamento. A monensina reduziu o teor de gordura no leite em $0,12 \%$ quando comparado às rações controle. Essa redução no teor de gordura parece que esta associada a rebanhos com dietas com percentual de carboidratos não fibrosos acima de 39,7\%, e baixo nível de fibra fisicamente efetiva, ou seja, mais de $45 \%$ das partículas menores que $8 \mathrm{~mm}$. Segundo Dubuc et al. (2009), dietas com níveis elevados de carboidratos não fibrosos e baixa porcentagem de fibra efetiva diminuem o ato de mastigação e diminuem a produção de bicarbonato na saliva, e este fato pode diminuir o $\mathrm{pH}$ ruminal, diminuir a biohidrogenização dos ácidos graxos de cadeia longa, aumentar a produção de ácido linoleico conjugado (CLA) e reduzir o teor de gordura no leite.

A monensina sódica reduziu o teor de gordura no leite em vários estudos, mas foram observadas grandes variações entre a monensina e a variável em questão. Estas variações podem ser explicadas devido à forma de suplementação e a dose de monensina utilizada, como os estudos de Phipps et al. (2000), Mackintosh et al. (2002), Duffield et al. (2002), Broderick (2004); Bell et al. (2006); Benchaar et al, (2006); Da Silva et al. (2008); Erasmus et al. (2008) e Oelker et al. (2009). A redução da gordura no leite pode ser explicada pela incompleta biohidrogenização dos ácidos graxos de cadeia longa no rúmen, que interfere com a síntese de novo dos mesmos na glândula mamária (BAUMAN ; GRIINARI, 2003). 
Fatores nutricionais como a composição da dieta e o manejo alimentar foram propostos para explicar a redução da gordura com a suplementação do ionóforo (DUFFIELD ; BAGG, 2002). No entanto, existem poucos estudos que investigaram essas interações da monensina com fatores nutricionais (DUFFIELD et al., 2002; ALZAHAL et al., 2008).

A suplementação com monensina pode diminuir a degradação ruminal das proteínas e aumentar a retenção de nitrogênio (SCHELLING, 1984; ALI-HAIMOUND et al. 1995), aumentando o fluxo de propionato e a biodisponlibilidade de lisina e metionina e outros aminoácidos no intestino delgado. Desta forma, a monensina pode aumentar o teor de proteína do leite (BECKETT et al., 1998).

McGuffey et al. (2001) analisaram dados de 11 experimentos com vacas suplementadas com premix de monensina sódica, e observaram efeito positivo $(\mathrm{P}<0,10)$ de $1,3 \mathrm{~kg}$ de leite em relação ao controle. Em revisão de 32 experimentos, Ipharraguerre e Clark (2003) relataram aumento da produção em 14 experimentos e no restante, não foi observado nenhum efeito da suplementação de monensina. Dentre os trabalhos avaliados positivamente, houve aumento na produção de leite de $1,5 \mathrm{~kg} / \mathrm{dia}$, que representou superioridade de 7\% em relação às rações controle.

No entanto, os dados observados na literatura contradizem o possível mecanismo de ação da monensina sobre o aumento do teor de proteína do leite, visto que a grande maioria dos estudos não observou nenhuma alteração (BELL et al., 2006, BENCHAAR et al. 2006, DA SILVA et al., 2008, ERASMUS et al., 2008, OELKER et al., 2009), ou ainda relataram diminuição desta variável, como citaram Hayes et al. (1996), Green et al. (1999), Phipps et al., (2000) e Broderick (2004). 


\subsubsection{Parâmetros Sanguíneos}

A monensina proporciona mudança nos parâmetros sanguineos de vacas leiteiras, principalmente no metabolismo energético através da glicose, ácidos graxos nãoesterificados e $\beta$-hidroxibutitato. Há também efeito da monensina sob o metabolismo protéico em nível plasmático, com alteração das concentrações de nitrogênio ureico plasmático (NUP). Quanto ao metabolismo lipídico, as poucas informações disponíveis na literatura mostram que não há efeito direto da monensina sob os níveis plasmáticos de colesterol total em vacas leiteiras lactantes.

Segundo estudo de Duffield et al. (2008), que avaliaram os efeitos da monensina no metabolismo de vacas leiteiras, constataram que a monensina aumenta em cerca de $3,0 \%$ os níveis de glicose e em $6,0 \%$ os níveis de uréia circulantes quando são comparados animais suplementados ou não com monensina. No entanto, não foi observado efeito algum da monensina sob as concentrações de colesterol total.

Da Silva et al. (2007) avaliaram a suplementação de monensina em dose de $20 \mathrm{mg} / \mathrm{kg}$ MS em vacas no início de lactação, e não encontraram nenhum efeito sobre o colesterol total, colesterol-HDL e triglicérides, no entanto observou efeito da monensina sobre a concentração plasmática de colesterol-LDL em relação à ração controle. De forma semelhante Gandra (2009), em experimento com vacas leiteiras suplementadas com monensina sódica nas concentrações de 0,24 e $48 \mathrm{mg} / \mathrm{Kg}$ de $\mathrm{MS}$, não foi observado efeito das rações experimentais nos níveis de colesterol total, colesterol-HDL e colesterol-LDL, estes se mostraram elevados para a ração 24 , enquanto que os valores de triglicérides e colesterol-VLDL não foram alterados. 
O aumento na concentração plasmática de glicose está relacionado ao aumento de propionato que chega ao fígado, devido à mudança do perfil fermentativo ruminal com a adição da monensina (MARTINEAU et al., 2007). Em relação ao NUP, a maior concentração plasmática pode estar associada à mudança da população bacteriana ruminal, causada pela adição da monensina que inibe as bactérias que deaminam as proteínas, diminuindo a concentração de $\mathrm{N}_{-} \mathrm{NH}_{3}$ ruminal, aumentando o fluxo de aminoácidos para o intestino delgado (SCHELLING, 1984).

A suplementação de monensina sódica em dietas de vacas leiteiras tem grande influência sobre a atividade das enzimas hepáticas aspartato aminotransferase e gamaglutamiltransferase, pois com a suplementação o aporte de propionato e aminoácidos aumentam em nível hepático, e por conseqüência acaba aumentando a atividade dessas enzimas no fígado. No entanto, mais estudos avaliando estas variáveis devem ser realizados para se fazer inferências concretas sobre esta questão (GANDRA et al., 2009).

\subsubsection{Resíduos de Monensina Sódica no Leite}

Diversos estudos tem sido conduzidos com objetivo de mensurar a existência de resíduos de monensina sódica no leite ou na carne de ruminantes. Segundo a Food and Agriculture Organization of the United Nations/World Health Organization (FAO/WHO) através do Codex Alimentarius Commission (2009), o limite máximo para a presença de monensina sódica no leite é da ordem de $2 \mu \mathrm{g} / \mathrm{L}$. Para a carne bovina esse valor está em torno de $10 \mu \mathrm{g} / \mathrm{kg}$, e sendo o fígado órgão de eleição para detecção de resíduos de monensina, limite máximo é de $20 \mu \mathrm{g} / \mathrm{kg}$. 
Wilkinson et al. (1997) reportaram que em oito estudos nos quais vacas leiteiras foram suplementadas com doses de monensina de 278 a $1125 \mathrm{mg} / \mathrm{dia}$, e foram realizadas análises de resíduos no leite, não foram observados valores que se caracterizavam como nocivos à saúde humana em nenhum dos estudos, apesar dos métodos de analise utilizados serem altamente sensíveis.

Da mesma forma, Bagg et al. (2005) suplementaram vacas leiteiras em início de lactação com doses crescentes de monensina de 72, 144, $240 \mathrm{mg} / \mathrm{kg} \mathrm{MS}$, e observaram drástica redução na produção de leite e no consumo de matéria seca nas doses de 144 e 240 $\mathrm{mg} / \mathrm{kg}$ MS, mas não detectaram resíduos de monensina que caracterizassem riscos à saúde humana. O valor do resíduo detectado de monensina para a dose de $240 \mathrm{mg} / \mathrm{kg} \mathrm{MS}$, que representa 10 vezes a dose usual, foi da ordem de $5 \mathrm{ng} / \mathrm{L}$.

Aparentemente, a utilização da monensina sódica para vacas leiteiras não traz qualquer risco a saúde humana, e os resíduos quando detectados são observados em valores baixíssimos, mesmo com doses muito elevadas do ionóforo e, além disso, estes resultados são obtidos em condições experimentais extremas, que geralmente não são utilizados em rações em sistemas de produção leiteira.

Segundo Gandra et al., (2009) relataram que no estudo feito em relação às concentrações residuais de monensina sódica no leite encontram-se dentro do limite máximo de $2 \mu \mathrm{g} / \mathrm{L}$ permitido pela FAO/WHO. Neste estudo foi observado os valores de 2,35 ng/L, para a ração controle; 3,52 ng/L para as rações com $24 \mathrm{mg} / \mathrm{kg}$ MS de monensina e 3,85 ng/L para as rações com $48 \mathrm{mg} / \mathrm{kg}$ MS de monensina. 


\section{MATERIAL E MÉTODOS}

\subsection{LOCAL, INSTALAÇÕES E ANIMAIS}

O experimento foi conduzido nas dependências do laboratório de pesquisa em bovinos (LPB) do Departamento de Nutrição e Produção animal (VNP) da Faculdade de Medicina Veterinária e Zootecnia da Universidade de São Paulo (FMVZ-USP), em Pirassununga, no período de 02 de dezembro de 2009 a 23 de fevereiro de 2010. Foram utilizadas 12 vacas da raça Holandesa com peso vivo médio de $580 \mathrm{~kg}$, entre 90 a 180 dias de lactação, e produção média de 30,0 kg/vaca/dia. Os animais foram agrupados em 3 quadrados latinos $4 \times 4$ balanceados e contemporâneos, com duração do período experimental de 21 dias, sendo 14 dias de adaptação e 7 dias de coleta de dados.

\subsection{RAÇÕES EXPERIMENTAIS E ANÁLISE DE ALIMENTOS}

Foram utilizadas as seguintes rações experimentais, formuladas segundo o NRC (2001): 1) Controle (C), composto por ração basal sem adição de monensina; 2) Monensina 12(M12), composto pela ração basal e a inclusão de $12 \mathrm{mg} / \mathrm{kg}$ MS de monensina sódica (Monensina Tortuga ${ }^{\circledR}$, Tortuga Companhia Zootécnica LTDA) na ração, e 3) Monensina 24(M24), composto pela ração basal e a inclusão de $24 \mathrm{mg} / \mathrm{kg}$ MS de monensina sódica (Monensina Tortuga ${ }^{\circledR}$, Tortuga Companhia Zootécnica LTDA) na ração, 4) Monensina 
48(M48), composto pela ração basal e a inclusão de $48 \mathrm{mg} / \mathrm{kg}$ MS de monensina sódica (Monensina Tortuga ${ }^{\circledR}$, Tortuga Companhia Zootécnica LTDA) na ração. A monensina foi adicionada ao concentrado. As respectivas rações, água e sal mineral foram fornecidos " $a d$ libitum” durante todo período experimental. $\mathrm{O}$ volumoso utilizado durante o experimento foi à silagem de milho. $\mathrm{O}$ volumoso e o concentrado foram oferecidos aos animais como dieta total.

Para melhor controle da administração da monensina sódica, foi formulado um premix com a monensina sódica (Monensina Tortuga ${ }^{\circledR}$, Tortuga Companhia Zootécnica LTDA.), que foi fornecido aos animais durante o período experimental, juntamente com o concentrado, em dose correspondente a 12, 24 ou $48 \mathrm{mg} / \mathrm{kg}$ MS de monensina sódica, exceto no tratamento controle, no qual os animais recebiam somente a dieta padrão.

Diariamente foram feitas pesagens das quantidades dos volumosos e concentrados fornecidos e das sobras de cada ração experimental, para estimativa do consumo individual. Os animais foram arraçoados de acordo com o consumo de matéria seca no dia anterior, de forma a ser mantido porcentual de sobras das dietas, diariamente, entre 5 e $10 \%$ do fornecido para não haver limitação de consumo. As amostras dos alimentos fornecidos foram coletadas e armazenadas a $-20^{\circ} \mathrm{C}$ para posteriores análises químico-bromatológicas.

As análises químico-bromatológicas foram realizadas no Laboratório de Nutrição Animal do Departamento de Nutrição e Produção Animal (VNP) da Faculdade de Medicina Veterinária e Zootecnia da Universidade de São Paulo (FMVZ-USP). A proporção dos ingredientes no concentrado e dieta total, assim como as respectivas composições bromatológica das rações experimentais e concentrados encontram-se nas tabelas 1, 2, 3 e 4. 
Tabela 1 - Proporção dos ingredientes do concentrado e das rações expressa na matéria seca (\% MS)

\begin{tabular}{lcc}
\hline Variáveis & Concentrado & Rações $^{1}$ \\
\hline Silagem de milho & - & 50,15 \\
Milho moído & 45,74 & 22,80 \\
Farelo de soja & 31,09 & 15,50 \\
Grão de soja & 16,07 & 8,01 \\
Uréia & 0,38 & 0,19 \\
Sulfato de amônia & 0,20 & 0,10 \\
Bicarbonato de sódio & 1,60 & 0,80 \\
Óxido de magnésio & 0,18 & 0,09 \\
Calcáreo & 0,28 & 0,14 \\
Agromix Leite & 3,97 & 1,98 \\
Sal comum & 0,48 & 0.24 \\
\hline
\end{tabular}

${ }^{1} \mathrm{C}=$ controle; $\mathrm{M} 12=12 \mathrm{mg} / \mathrm{kg}$ MS da raçào de monensina sódica; $\mathrm{M} 24=24 \mathrm{mg} / \mathrm{kg}$ MS da ração de monensina sódica; M48= $48 \mathrm{mg} / \mathrm{kg}$ MS da ração de monensina sódica. ${ }^{2}$ Composição por $\mathrm{kg}$ de mistura mineral: Ca190g; P 73g; Mg 44g; S 30g; Na 62g; Zn 1.350mg; Cu 340mg; Mn 940mg; Fe $1.064 \mathrm{mg}$; Co 3mg; I 16mg; Se 10mg; F(máx.)730mg.

Tabela 2 - Composição bromatológica do concentrado experimental

\begin{tabular}{lc}
\hline Variáveis & Concentrado experimental $^{1}$ \\
\hline Materia seca & 86,33 \\
Materia orgânica & 87,36 \\
Proteina bruta & 27,97 \\
Extrato etéreo & 6,59 \\
Carboidratos totais & 53,64 \\
Fibra em detergente neutro & 13,93 \\
Carboidratos não fibrosos & 67,01 \\
Fibra em detergente ácido & 8,74 \\
Lignina & 1,39 \\
Materia mineral & 5,53 \\
NDT $^{2}$ & 79,64 \\
ELL $^{3}(\mathrm{Mcal} / \mathrm{kg})$ & 2,14 \\
\hline${ }^{1} \mathrm{C}=$ controle; $^{\mathrm{M} 12}=12 \mathrm{mg} / \mathrm{kg}$ MS da raç̀o de monensina sódica; M24=
\end{tabular}

${ }^{1} \mathrm{C}=$ controle; $\mathrm{M} 12=12 \mathrm{mg} / \mathrm{kg}$ MS da raçào de monensina sódica; $\mathrm{M} 24=$ $24 \mathrm{mg} / \mathrm{kg}$ MS da ração de monensina sódica; M48=48 mg/kg MS da ração de monensina sódica ${ }^{2}$ NDT (nutrientes digestíveis totais); ${ }^{3}$ ELL (energia líquida de lactação). 
Tabela 3 - Composição bromatológica das dietas experimentais

\begin{tabular}{|c|c|}
\hline Variáveis & Rações experimentais ${ }^{1}$ \\
\hline Materia seca & 63,61 \\
\hline Materia orgânica & 91,19 \\
\hline Proteina bruta & 18,08 \\
\hline Extrato etéreo & 5,15 \\
\hline Carboidratos totais & 68,49 \\
\hline $\mathrm{NIDN}^{2}$ & 17,58 \\
\hline $\mathrm{NIDA}^{3}$ & 16,05 \\
\hline Fibra em detergente neutro & 34,09 \\
\hline Carboidratos não fibrosos & 51,93 \\
\hline Fibra em detergente ácido & 21,38 \\
\hline Lignina & 2,66 \\
\hline Materia mineral & 9.77 \\
\hline $\mathrm{NDT}^{4}$ & 72,08 \\
\hline $\mathrm{EL}_{\mathrm{L}}^{5}(\mathrm{Mcal} / \mathrm{kg})$ & 1,60 \\
\hline Energia Bruta (Mcal/kg MS) & 3,89 \\
\hline \multicolumn{2}{|c|}{$\begin{array}{l}{ }^{1} \mathrm{C}=\text { controle; } \mathrm{M} 12=12 \mathrm{mg} / \mathrm{kg} \text { MS da raçào de monensina sódica; } \mathrm{M} 24=24 \\
\mathrm{mg} / \mathrm{kg} \text { MS da ração de monensina sódica; } \mathrm{M} 48=48 \mathrm{mg} / \mathrm{kg} \text { MS da ração de } \\
\text { monensina sódica. }{ }^{2} \mathrm{NIDN} \text { (nitrogênio insolúvel em detergente neutro); } \\
{ }^{3} \mathrm{NIDA} \text { (nitrogênio insolúvel em detergente ácido); NDT (nutrientes } \\
\text { digestíveis totais) } ;{ }^{4} \text { ELL (energia líquida de lactação). }\end{array}$} \\
\hline
\end{tabular}

Tabela 4 - Composição químico-bromatológica dos nutrientes do concentrado e da silagem de milho

\begin{tabular}{|c|c|c|c|c|}
\hline Itens & $\begin{array}{c}\text { Silagem } \\
\text { de } \\
\text { Milho }\end{array}$ & $\begin{array}{c}\text { Farelo } \\
\text { de } \\
\text { Soja }\end{array}$ & $\begin{array}{l}\text { Milho } \\
\text { Moído }\end{array}$ & $\begin{array}{c}\text { Grão de } \\
\text { Soja }\end{array}$ \\
\hline Matéria seca & 34,15 & 82,88 & 84,72 & 91,62 \\
\hline Matéria orgânica & 95,04 & 94,3 & 93,57 & 94,87 \\
\hline Matéria mineral & 4,95 & 5,70 & 6,43 & 5,12 \\
\hline Proteína Bruta & 7,85 & 53,0 & 9,96 & 39,10 \\
\hline $\mathrm{NIDN}^{1}$ & 21,12 & 18,83 & 12,24 & 17,46 \\
\hline $\mathrm{NIDA}^{2}$ & 13,29 & 3,97 & 11,50 & 4,07 \\
\hline Extrato etéreo & 3,93 & 3,36 & 3,69 & 22,79 \\
\hline Carboidratos totais & 83,27 & 37,94 & 79,92 & 32,99 \\
\hline $\mathrm{FDN}^{3}$ & 54,16 & 19,67 & 12,51 & 13,04 \\
\hline $\mathrm{CNF}^{4}$ & 36,96 & 71,27 & 77,37 & 59,05 \\
\hline FDA $^{5}$ & 33,99 & 14,90 & 4,56 & 12,62 \\
\hline $\mathrm{FDAi}^{6}$ & 12,17 & 1,55 & 1,20 & 0,99 \\
\hline Lignina & 3,96 & 1,60 & 0,88 & 3,05 \\
\hline $\mathrm{NDT}^{7}$ & 64,60 & 80,29 & 82,32 & 106,0 \\
\hline $\mathrm{EL}_{\mathrm{L}}^{8}(\mathrm{Mcal} / \mathrm{kg})$ & 1,52 & 2,40 & 2,00 & 3,00 \\
\hline $\mathrm{EB}^{9}(\mathrm{cal} / \mathrm{g} / \mathrm{MS})$ & 3919,1 & 4279,5 & 3764,3 & 5118,7 \\
\hline
\end{tabular}

$\mathrm{C}=$ Controle; M12= $12 \mathrm{mg} / \mathrm{kg}$ MS da ração de monensina sódica; M24= $24 \mathrm{mg} / \mathrm{kg}$ MS da ração de monensina sódica; M48=48 mg/kg MS da ração de monensina sódica. ${ }^{1} \mathrm{NIDN}$ (nitrogênio insolúvel em detergente neutro); ${ }^{2} \mathrm{NIDA}$ (nitrogênio insolúvel em detergente ácido); ${ }^{3} \mathrm{FDN}$ (fibra em detergente neutro); ${ }^{4} \mathrm{CNF}$ (carboidratos não-fibrosos); ${ }^{5} \mathrm{FDA}$ (fibra em detergente ácido); ${ }^{6} \mathrm{FDAi}$ ( fibra em detergente ácido indigestível); ${ }^{7} \mathrm{NDT}$ (nutrientes digestíveis totais estimados); ${ }^{8} \mathrm{EL}_{1}$ (energia líquida de lactação). ${ }^{9} \mathrm{~EB}$ (energia bruta). ${ }^{9}$ Obtido em bomba calorimétrica. 
Nos alimentos fornecidos e nas amostras de sobras foram analisados os teores de matéria seca (MS), matéria orgânica (MO), matéria mineral (MM), extrato etéreo (EE), proteína bruta (PB), nitrogênio insolúvel em detergente neutro (NIDN), nitrogênio insolúvel em detergente ácido (NIDA) e lignina de acordo com as metodologias descritas por Silva \& Queiroz (2002). O teor de proteína bruta (PB) foi obtido pela multiplicação do teor de nitrogênio total por 6,25.

Os carboidratos totais (CT) foram calculados segundo Sniffen et al. (1992), em que: $\mathrm{CT}=100-(\% \mathrm{~PB}+\% \mathrm{EE}+\% \mathrm{MM})$. Os teores de carboidratos não-fibrosos $(\mathrm{CNF})$ foram estimados segundo Hall (1998) onde: $\mathrm{CNF}=100-[(\% \mathrm{~PB}-\% \mathrm{~PB}$ Uréia $+\%$ Uréia $)+\% \mathrm{EE}$ $+\% \mathrm{MM}+\% \mathrm{FDN}]$. Os nutrientes digestíveis totais foram calculados conforme equações do NRC (2001), em que: NDT $=$ CNFD + PBD + (AGD * 2,25) + FDND - 7, onde PBD, CNFD, FDND e AGD representam o total destes nutrientes digestíveis. Os nutrientes digestíveis totais observados NDT $=\mathrm{PBd}+\mathrm{FDNd}+(\mathrm{EEd} * 2,25)+\mathrm{CNFd}$ foram calculados de acordo com Weiss et al. (1992).

Os teores de fibra detergente neutro (FDN), fibra detergente neutro livre de cinza e proteína (FDNcp), e fibra detergente ácido (FDA) foram obtidos conforme método descrito por Van Soest et al. (1984), utilizando-se $\alpha$-amilase e sem adição de sulfito de sódio na determinação do FDN, em Sistema Ankon®. 


\subsection{DIGESTIBILIDADE APARENTE TOTAL}

$\mathrm{Na}$ determinação da digestibilidade aparente total da matéria seca e dos nutrientes a quantidade total de matéria seca fecal excretada foi estimada pela concentração de fibra em detergente ácido indigestível (FDAi). As fezes foram coletadas no $17^{\circ}, 18^{\circ}$ e $19^{\circ}$ dias de cada período experimental, sempre antes das ordenhas da manhã e da tarde, sendo acondicionadas em sacos plásticos e armazenadas em freezer à $-20^{\circ} \mathrm{C}$, e ao final do período de coleta foi feita à amostra composta por animal com base no peso seco ao ar.

As amostras de silagem, sobras e fezes foram pré-secas em estufa com ventilação forcada $\left(60^{\circ} \mathrm{C} / 72\right.$ horas $)$, e, em conjunto com as demais amostras de ingredientes, foram processadas em moinho de facas com peneiras de porosidade $2 \mathrm{~mm}$.

Para avaliação dos teores dos componentes indigestíveis, as amostras processadas foram acondicionadas em sacos de tecido não-tecido (TNT-100g/m2), com dimensões de 4 x $5 \mathrm{~cm}$. As alíquotas foram acondicionadas em todos os sacos, segundo a relação de $20 \mathrm{mg}$ de matéria seca por centímetro quadrado de superfície (NOCEK, 1988).

Antes da incubação das amostras duas vacas da raça Holandesa foram adaptadas durante 7 dias com concentrado a base de farelo de soja e milho moído, e recebendo silagem de milho como volumoso. Posteriormente ao período de adaptação dos animais, as amostras foram incubadas no rúmen por período de 240 horas, segundo adaptação de técnica descrita por Casali (2006).

Após a retirada do rúmen os sacos foram lavados com água corrente até o total clareamento desta, e imediatamente conduzidos à estufa de ventilação forçada $\left(60^{\circ} / 72\right.$ horas). Após este período, os sacos foram submetidos à secagem em estufa não ventilada 
(105\%/45 minutos), sendo retirados, acondicionados em dessecador (20 sacos/dessecador), e pesados, obtendo-se a matéria seca indigestível.

Posteriormente, os sacos foram submetidos ao tratamento com detergente ácido (MERTENS, 2002) por 1 hora, em equipamento analisador de fibra Ankon®. Após este período foram lavados com água quente e acetona, sendo secos e pesados conforme procedimento anterior. Ao final deste tratamento, obteve-se a FDAi.

\subsection{FERMENTAÇÃO RUMINAL}

Para avaliação dos parâmetros de fermentação ruminal as amostras de líquido ruminal foram coletadas com a utilização de sonda esofágica três horas (tempo três) após a alimentação da manhã. Logo após a coleta foram determinados os valores de $\mathrm{pH}$ ruminal utilizando potenciômetro. As amostras foram armazenadas em caixa térmica e encaminhadas ao Laboratório de Nutrição Animal do VNP-FMVZ-USP.

No laboratório as amostras foram centrifugadas a $2000 \mathrm{~g}$ por 15 minutos, $1 \mathrm{ml}$ do sobrenadante foi colocado em tubo de ensaio e adicionando-se $0,2 \mathrm{ml}$ de ácido fórmico P.A., arrolhado e identificado e armazenado em congelador a $-20^{\circ} \mathrm{C}$ para determinação de ácido graxos de cadeia curta. Da mesma amostra $2 \mathrm{ml}$ do sobrenadante foi pipetado e armazenado em tubos de ensaio contendo $1 \mathrm{ml}$ de acido sulfúrico a $1 \mathrm{~N}$, para posterior determinação da concentração de nitrogênio amoniacal $\left(\mathrm{N}-\mathrm{NH}_{3}\right)$.

A analise de ácidos graxos de cadeia curta foi realizada utilizando cromatógrafo a gás (Modelo 9001 Gas Chromatograph, Marca Finnigan) equipado com coluna de vidro de 02 metros de comprimento x 1/4”, empacotada com 80/120 Carbopack B-DA/4\% Carbowax 
20M. Os gases utilizados foram o nitrogênio como gás de arraste na vazão de $25 \mathrm{ml} / \mathrm{minuto}$, oxigênio como gás comburente na vazão de $175 \mathrm{ml} /$ minuto, e hidrogênio como gás combustível na vazão de $15 \mathrm{ml} /$ minuto. As temperaturas utilizadas do vaporizador foi de $220^{\circ} \mathrm{C}$, do detector de ionização de chamas de $250^{\circ} \mathrm{C}$ e da coluna de separação de $195^{\circ} \mathrm{C}$ por 03 minutos, aumentando $10{ }^{\circ} \mathrm{C} /$ minuto até $200{ }^{\circ} \mathrm{C}$.

Soluções padrões a 0,1 Normal de ácido acético, propiônico e butírico foram preparadas e padronizadas com hidróxido de potássio $(\mathrm{KOH})$ 0,1 Normal, a fim de produzir solução padrão de ácidos graxos de cadeia curta de concentração conhecida. As determinações foram realizadas injetando-se 1,0 $\mu 1$ de amostra em cromatógrafo integrado a computador, que processava os cálculos de quantificação, utilizando-se do software BORWIN versão 1.21 para cromatografia.

$\mathrm{O}$ nitrogênio amoniacal $\left(\mathrm{N}-\mathrm{NH}_{3}\right)$ foi determinado pelo método de ácido salicílico. Foram adicionados aos tubos contendo amostras de líquido ruminal, acido sulfúrico a 1, 1 $\mathrm{ml}$ de tungstato de sódio a $10 \%$, e posteriormente as amostras foram centrifugadas a $1200 \mathrm{~g}$ durante 15 minutos. Em seguida foram pipetados $25 \mu 1$ do sobrenadante a um tubo limpo e neste adicionados $5 \mathrm{ml}$ do reagente fenol e $5 \mathrm{ml}$ de hipoclorito.

Os tubos foram agitados para homogeneização das amostras e colocados em banho maria a $37^{\circ} \mathrm{C}$ durante 15 minutos adquirindo coloração azul. Após resfriamento as amostras foram analisadas em espectrofotômetro quanto a sua absorbância e os resultados obtidos foram utilizados em equação de regressão para calcular a concentração em mg/dl, onde: Concentração de $\mathrm{N}-\mathrm{NH}_{3}(\mathrm{mg} / \mathrm{dl})=$ Absorbância $-(\mathrm{a}) / \mathrm{b} ; \mathrm{b}=\mathrm{r}^{2}$ da equação elaborada a partir do padrão. 


\subsection{SÍNTESE DE PROTEÍNA MICROBIANA}

As análises para determinação da síntese de proteína microbiana foram realizadas no Laboratório de Bioquímica e Fisiologia Animal do VNP-FMVZ-USP. As amostras utilizadas para análise de alantoína no leite foram coletadas de dois dias alternados, sendo provenientes das duas ordenhas diárias. Uma alíquota de $10 \mathrm{ml}$ de leite foi diluída com $5 \mathrm{ml}$ de ácido tricloroacético a $25 \%$, sendo filtrada em papel-filtro e congelada para posterior determinação dos níveis de uréia e alantoína no leite desproteinizado. Alíquotas de $50 \mathrm{ml}$ de urina (amostra spot) foram obtidas de todas as vacas no $16^{\circ}$ dia do período experimental, aproximadamente 4 horas após a alimentação, durante micção estimulada por massagem na vulva. A urina foi filtrada e alíquotas de $10 \mathrm{ml}$ foram diluídas imediatamente em $40 \mathrm{ml}$ de ácido sulfúrico a $0,036 \mathrm{~N}$ para evitar destruição bacteriana dos derivados de purinas e precipitação do ácido úrico. Uma amostra de urina pura foi armazenada para determinação dos compostos nitrogenados totais, de uréia e creatinina.

As concentrações de creatinina foram determinadas por meio de kits comerciais (Laborlab®), utilizando reação enzimática calorimétrica cinética em aparelho SBA-200 Celm ${ }^{\circledR}$. O volume urinário total diário foi estimado dividindo-se as excreções urinárias diárias de creatinina pelos valores observados de concentração de creatinina na urina das amostras spot, segundo Oliveira et al. (2001).

A excreção urinária diária de creatinina foi estimada a partir da excreção média diária, estabelecida de 24,05 mg/kg de peso vivo para vacas leiteiras (CHIZZOTTI, 2004). Dessa forma, com a excreção média diária de creatinina e a concentração de creatinina (mg/dl) na amostra spot de urina, foi estimado o volume total diário de urina, em litros por vaca/dia. Os níveis de alantoína na urina e os de ácido úrico na urina e alantoína do leite foram 
determinados pelo método colorimétrico, conforme metodologia de Fujihara et al. (1987), descrita por Chen e Gomes (1992).

A excreção total de derivados de purinas foi calculada pela soma das quantidades de alantoína e ácido úrico excretadas na urina e da quantidade de alantoína excretada no leite, expressas em mmol/dia. As purinas microbianas absorvidas (Pabs, mmol/dia) foram calculadas a partir da excreção de derivados de purinas (DP, mmol/dia), por meio da equação Pabs=(DP-0,236*PV $\left.{ }^{0,75}\right) / 0,84$, em que 0,84 é a recuperação de purinas absorvidas como derivados de purina e $0,236^{*} \mathrm{PV}^{0,75}$, a excreção endógena de derivados de purina (ORELLANA BOERO et al., 2001).

Foram avaliadas também as purinas absorvidas, considerando-se a excreção endógena de $0,512 * \mathrm{PV}^{0,75}$ e a recuperação de 0,70 encontradas por Gonzalez- Ronquillo et al. (2003). A síntese ruminal de compostos nitrogenados (Nmic, gN/dia) foi calculada com base nas purinas absorvidas (Pabs, mmol/dia), utilizando-se a equação (CHEN \& GOMES, 1992): Nmic $=(70 *$ Pabs $) /(0,83 * 0,134 * 1.000)$, em que 70 é o conteúdo de $\mathrm{N}$ nas purinas (mgN/mol); 0,134, a relação N purina: $\mathrm{N}$ total nas bactérias (VALADARES et al., 1999); e 0,83, a digestibilidade intestinal das purinas microbianas.

\subsection{BALANÇO DE ENERGIA E DE NITROGÊNIO}

Para obtenção do consumo de energia bruta e realização do cálculo da eficiência do uso de energia consumida, as amostras de silagem, ingredientes e concentrados foram analisadas quanto ao seu teor de energia bruta em bomba calorimétrica, de acordo com Harvatine e Allen (2006). O consumo de energia digestível (CED) foi obtido por meio do 
coeficiente de digestibilidade das rações experimentais e do consumo de energia bruta, de acordo com os valores de energia obtidos para os ingredientes do concentrado e a silagem de milho (HARVATINE; ALLEN, 2006).

O consumo de energia líquida (CEL), os valores de energia líquida de produção $\left(E L_{P}\right)$, energia líquida de ganho $\left(\mathrm{EL}_{\mathrm{g}}\right)$, e mudança de peso de corpo vazio (MPCV) foram calculados de acordo com as equações do NRC (2001), a seguir: CEL (Mcal/dia) $=0,703 \times$ $\mathrm{EM}($ consumo $)-0,19+\{[(0,097 \times \mathrm{EM}($ consumo $)+0,19) / 97] \times[\mathrm{EE}-3]\} ; \mathrm{EM}($ consumo $)$ $=1,01 \times(\mathrm{ED}($ consumo $)-0,45]+0,0046 \times(\mathrm{EE}-3)$ onde: $\mathrm{EM}=$ energia metabolizável; $\mathrm{EE}=$ extrato etéreo; $\mathrm{ED}=$ energia digestível.

Os valores de energia metabolizável (EM) foram obtidos pela seguinte fórmula: EM $(\mathrm{Mcal} / \mathrm{kg})=[1,01 *\{(\% \mathrm{CNF} / 100) * 4,2+(\% \mathrm{FDN} / 100) * 4,2+(\% \mathrm{~PB} / 100) * 5,6+$ $(\% \mathrm{AG} / 100) * 9,4-03)\}-0,45]+0,0046 *(\mathrm{EE}-3,0)$.

Os valores de energia líquida de produção $\left(\mathrm{EL}_{\mathrm{P}}\right)$ foram calculados segundo a fórmula: $\mathrm{EL}_{\mathrm{p}}(\mathrm{Mcal} / \mathrm{dia})=$ produção de leite $(\mathrm{kg}) \times(0,0929 \times \mathrm{G} \%+0,0563 \times \mathrm{PV} \%+0,0395 \times$ lactose\%) onde: G\%=teor de gordura no leite; $\mathrm{PV}=$ teor de proteína verdadeira do leite.

A mudança de peso de corpo vazio (MPCV) foi calculada a parti do peso vivo (PV) onde: $\mathrm{PCV}=0,817^{*} \mathrm{PV}$. A energia líquida de ganho foi calculada através da fórmula: $\mathrm{EL}_{\mathrm{G}}$ $=1,42 \mathrm{EM}-0,174 * \mathrm{EM}+0,0122 * \mathrm{EM}^{*} 1,65$.

A eficiência de utilização de energia foi calculada de acordo com Harvatine e Allen (2006), da seguinte forma: Eficiência produção de leite = EL (consumo) - EL(ganho PV) + EL(leite); Eficiência lactação = EL produção de leite + EL ganho de PV)/Consumo de ED.

Para o cálculo de balanço de nitrogênio foi realizada a determinação da concentração de creatinina na urina de acordo com metodologia descrita por Valadares et al. (1999) e Rennó (2003). 
As amostras spot de urina foram obtidas de todas as vacas no $16^{\circ}$ dia de cada período experimental, quatro horas após a alimentação matinal, durante micção estimulada por massagem na vulva. A urina foi filtrada e alíquotas foram armazenadas a $-15^{\circ} \mathrm{C}$ para posteriores análises de nitrogênio total e creatinina.

As concentrações de creatinina foram determinadas por meio de kits comerciais (Laborlab®), utilizando reação enzimática calorimétrica cinética em aparelho SBA-200 Celm ${ }^{\circledR}$. Para a realização dessa análise, $100 \mu 1$ de urina foram diluídos em $4900 \mu 1$ de água deionizada. Os resultados obtidos foram calculados pela seguinte fórmula: Creatinina $(\mathrm{mg} / \mathrm{dl})=$ creatinina $(\mathrm{mg} / \mathrm{dl}) * 0,020 * 50($ Biggs $;$ Copper, 1961$)$.

O volume urinário total diário foi estimado dividindo-se as excreções urinárias diárias de creatinina pelos valores observados de concentração de creatinina na urina das amostras spot, segundo Oliveira et al. (2001). A excreção urinária diária de creatinina foi estimada a partir da proposição de 24,05 mg/kg de peso vivo (CHIZZOTTI, 2004).

Dessa forma, com a excreção média diária de creatinina e a concentração de creatinina $(\mathrm{mg} / \mathrm{dl})$ na amostra spot de urina, foi estimado o volume total diário de urina, em litros por vaca/dia, para o cálculo do balanço de nitrogênio.

O consumo de nitrogênio foi determinado retirando-se o valor de conversão de nitrogênio total das amostras para obtenção do valor de proteína bruta $(6,25)$, obtendo-se a quantidade em gramas de nitrogênio consumida. O mesmo cálculo foi realizado com os valores de proteína bruta das fezes obtendo-se a excreção total de nitrogênio em g/kg MS.

O nitrogênio total das amostras de urina e leite foi determinado de acordo com as metodologias descritas por Silva e Queiroz (2002), onde a quantidade em gramas de nitrogênio para cada $100 \mathrm{ml}$ de urina ou leite foi obtido dividindo-se o valor de proteína bruta das amostras pelo fator 6,25 para as amostras de urina e do fator 6,38 para as amostras de leite. 
O balanço de nitrogênio foi obtido subtraindo o total de nitrogênio em gramas consumido pelos valores de nitrogênio na urina, fezes e leite, obtendo-se os valores de nitrogênio retido em gramas e em porcentagem do nitrogênio total.

\subsection{PRODUÇÃO E COMPOSIÇÃO DO LEITE}

As vacas foram ordenhadas mecanicamente duas vezes ao dia, as 6:30 e as 15:30 horas, sendo a produção de leite registrada diariamente durante todo o período experimental. A produção de leite foi corrigida para 3,5\% de gordura (PLC) segundo fórmula de Sklan et al. $(1992)$, onde PLC $=(0,432+0,1625 *$ teor de gordura do leite $) * \mathrm{Kg}$ de leite. Foi determinado o teor de gordura e proteína do leite.

As amostras utilizadas para análise da composição do leite foram obtidas no $16^{\circ}$ de cada período experimental, sendo cada amostra proveniente das duas ordenhas diárias. Foram determinados também os teores de gordura, proteína e lactose. Para a determinação da gordura no leite foram utilizadas amostras à fresco, segundo a metodologia descrita por Gerber (COELHO ; ROCHA, 1977) no Laboratório de Tecnologia de Produtos de Origem Animal do VNP-FMVZ-USP. Também foram realizadas as análises no leite de nitrogênio total (NT) e lactose utilizando o equipamento LACTOSCAN no Laboratório de Bioquímica e Fisiologia Animal do Departamento de Nutrição e Produção Animal da FMVZ-USP. Para determinação da uréia e nitrogênio uréico no leite, as amostras de leite foram desproteinizadas da mesma forma que as amostras utilizadas na análise da alantoína. As análises da concentração de uréia no leite desproteinizado foram realizadas no Laboratório de Bioquímica e Fisiologia Animal do Departamento de Nutrição e Produção Animal da 
FMVZ-USP, por meio de kits comerciais (Laborlab® e CELM®). A concentração de nitrogênio uréico no leite foi determinada indiretamente por meio da seguinte fórmula: Nitrogênio uréico $=$ uréia $(\mathrm{mg} / \mathrm{dL}) / 2,14$.

\subsection{AVALIAÇÃO DO ESCORE DE CONDIÇÃO CORPORAL E PESO CORPORAL}

O escore de condição corporal (ECC) e o peso corporal foram avaliados no sétimo dia de adaptação e no final de cada período experimental, para avaliação da variação de peso.

O peso dos animais foi correspondente à média de duas pesagens sucessivas, feitas antes do fornecimento das alimentações e após as ordenhas durante dois dias. Para o cálculo da variação de ECC e de peso corporal, foram considerados os pesos do sétimo dia de adaptação e do final de cada período experimental. As mensurações do ECC foram realizadas segundo metodologia proposta por Wildman et al. (1982) e desenvolvida por Edmonson et al. (1989).

\subsection{PARÂMETROS SANGUÍNEOS}

As coletas de sangue foram realizadas no $19^{\circ}$ dia de cada período experimental por punção da veia e/ou artéria coccígea, anteriormente ao fornecimento das rações no período da manhã. As amostras foram coletadas em tubos vacuolizados (vacutainer) de $10 \mathrm{ml}$ para dosagem dos parâmetros sanguíneos triglicérides, colesterol total, colesterol-HDL, proteínas 
totais, albumina, uréia e nitrogênio ureico, as enzimas aspartato aminotransferase (AST) e gama glutamil transferase (GTA), no soro, e tubos contendo fluoreto de sódio para dosagem de glicose no plasma.

Imediatamente após coleta as amostras foram coletadas refrigeradas e centrifugadas a 2000 g durante 15 minutos, para a separação do soro ou plasma. O centrifugado obtido foi transferido para tubetes plásticos, identificados e armazenados a $-20^{\circ} \mathrm{C}$, até o procedimento das análises laboratoriais.

As análises das concentrações dos parâmetros sanguíneos foram realizadas no Laboratório de Bioquímica e Fisiologia Animal do VNP-FMVZ-USP, por meio de kits comerciais $\left(\right.$ Laborlab ${ }^{\circledR}$ e $\left.C E L M \circledR\right)$ que utilizam método enzimático colorimétrico de ponto final ou cinético, sendo a leitura realizada em analisador automático de bioquímica sanguínea (Sistema de Bioquímica Automático SBA-200 - CELM®).

A concentração de Colesterol HDL (C-HDL) foi determinada em duas etapas, sendo a primeira envolvendo preparação previa das amostras, e a segunda a análise propriamente dita. Para a realização da análise da concentração de C-HDL, $200 \mu \mathrm{l}$ da amostra foram pipetados em tubos Ependorff de $2,5 \mathrm{ml}$, juntamente com $100 \mu \mathrm{l}$ do reativo único precipitante (CELM-1763) na proporção de 2:1 e misturados manualmente por inversão suave durante 20 segundos. Em seguida as amostras foram deixadas em repouso por 10 minutos. Posteriormente, as amostras preparadas foram centrifugadas durante 15 minutos a 2700 g. Nos volumes centrifugados, as lipoproteínas LDL e VLDL foram precipitadas seletivamente pelo ácido fosfotugstico. No sobrenadante, separado pela centrifugação, restaram as moléculas de HDL ligadas ao colesterol.

A concentração de C-HDL foi determinada pela concentração de moléculas de colesterol, através do sistema enzimático-colorimétrico com o kit comercial CELM-1755. As concentrações de colesterol-LDL e colesterol-VLDL foram determinadas indiretamente, 
por meio de fórmulas, onde: VLDL colesterol $(\mathrm{mg} / \mathrm{dl})=($ concentração de triglicérides/5) e LDL colesterol $(\mathrm{mg} / \mathrm{dl})=$ Colesterol Total $-($ HDL Colesterol + VLDL Colesterol). (FRIEDEWALD et al., 1972).

\subsection{RESIDUOS DE MONENSINA NO LEITE}

Para as análises do resíduo de monensina sódica no leite foram coletadas amostras de leite em cada período experimental, de todos os animais. Posteriormente as amostras foram encaminhadas para o Laboratório de Alta Tecnologia (LABTEC®), situado em Campinas, SP. O método utilizado para a análise dos resíduos de monensina no leite foi a espectrometria de massa, utilizando cromatografia líquida de ultra performance (UPLC_MS/MS). As etapas de análise consistiram em extração do ativo monensina, reconstituição da amostra extraída e leitura da amostra em cromatografia líquida de ultra performance (UPLC_MS/MS) (BLANCHFLOWER \& KENNEDY, 1996).

A extração procedeu-se primeiramente com a mistura do leite com acetonitrila, logo após essa mistura foi agitada por 40 segundos num agitador de tubos e centrifuga por 3 min a $3500 \mathrm{rpm}$. Posteriormente as amostras foram transferidas para um cartucho de extração oásis HLB, a coluna foi eluida com $2 \mathrm{ml}$ de acetonitrila. Em seguida, as amostras foram secadas em concentrador com fluxo de argônio e temperatura de $45^{\circ} \mathrm{C}$. Posteriormente as amostras foram reconstituídas com acetonitrila.

A quantificação do ativo monensina foi feita utilizando maduramicina como padrão interno. A separação cromatográfica dos ativos é conseguida usando coluna C 18 (50 mm × $2.1 \mathrm{~mm} \times 1.7 \mu \mathrm{m})$, com a fase móvel sendo composta por gradiente isocratico sendo. Fase móvel A: água com Hac / fase móvel A: acetonitrila com Hac. O volume de injeção foi de 
5 ul e o tempo de análise foi de 3 min, por amostra. O tempo de retenção do analito foi de 1.73min / tempo de retenção do padrão interno: 2.03 min (CHÉNEAU et al., 2006).

\subsection{ANÁLISES ESTATÍSTICAS}

Os dados obtidos foram submetidos à análise de variância e regressão polinomial pelo comando PROC MIXED do SAS, versão 9.0 (SAS, 2009), adotando-se nível de significância de 5\%. As médias foram ajustadas pelo LSMEANS e analisadas pelo teste de Tukey ajustado do PROC MIXED. 


\section{RESULTADOS E DISCUSSÃO}

\subsection{CONSUMO}

A utilização de monensina sódica nas rações resultou em efeito linear decrescente $(\mathrm{P}<0,05)$ do consumo de matéria seca, matéria orgânica, proteína bruta, extrato etéreo, carboidratos totais, fibra detergente neutro, carboidratos não fibrosos, nutrientes digestíveis totais (Tabela 5). No entanto, analisando a comparação das medias ajustadas verifica-se que somente no maior nível de utilização de monensina, $48 \mathrm{mg} / \mathrm{kg} \mathrm{MS}$, foi observada redução do consumo em relação a dieta controle. Os resultados se repetem quando são comparadas as variáveis em $\mathrm{kg} / \mathrm{dia}$ e em porcentagem do peso vivo dos animais.

Tabela 5 - Médias ajustadas e erro padrão da média (EPM) do consumo de matéria seca (CMS) e nutrientes em função das rações experimentais

\begin{tabular}{|c|c|c|c|c|c|c|c|c|}
\hline \multirow{2}{*}{ Variáveis } & \multicolumn{4}{|c|}{ Dietas experimentais ${ }^{1}$} & \multirow{2}{*}{ Média } & \multirow{2}{*}{ EPM } & \multicolumn{2}{|c|}{$\overline{\mathrm{P}^{2}}$} \\
\hline & $\mathrm{C}$ & M12 & M24 & M48 & & & $\mathrm{L}$ & $\mathrm{Q}$ \\
\hline \multicolumn{9}{|c|}{ Consumo kg/dia } \\
\hline $\mathrm{MS}^{3}$ & $20,34^{\mathrm{a}}$ & $19,95^{\mathrm{a}}$ & $19,86^{\mathrm{a}}$ & $16,76^{b}$ & 19,22 & 0,43 & $<0,001$ & $<0,001$ \\
\hline $\mathrm{MO}^{4}$ & $18,30^{\mathrm{a}}$ & $17,87^{\mathrm{a}}$ & $17,72^{\mathrm{a}}$ & $15,19^{b}$ & 17,27 & 0,40 & $<0,001$ & 0,004 \\
\hline $\mathrm{PB}^{5}$ & $3,88^{\mathrm{a}}$ & $3,80^{\mathrm{a}}$ & $3,77^{\mathrm{a}}$ & $3,18^{b}$ & 3,65 & 0,08 & $<0,001$ & $<0,001$ \\
\hline $\mathrm{EE}^{6}$ & $1,09^{\mathrm{a}}$ & $1,06^{\mathrm{a}}$ & $1,05^{\mathrm{a}}$ & $0,89^{\mathrm{b}}$ & 1,02 & 0,02 & $<0,001$ & $<0,001$ \\
\hline $\mathrm{CT}^{7}$ & $13,34^{\mathrm{a}}$ & $13,00^{\mathrm{a}}$ & $12.89^{\mathrm{a}}$ & $11,11^{b}$ & 12,58 & 0,34 & $<0,001$ & $<0,001$ \\
\hline $\mathrm{FDN}^{8}$ & $6,51^{\mathrm{a}}$ & $6,37^{\mathrm{a}}$ & $6,34^{\mathrm{a}}$ & $5,44^{\mathrm{b}}$ & 6,16 & 0,15 & $<0,001$ & 0,003 \\
\hline $\mathrm{CNF}^{9}$ & $8,24^{\mathrm{a}}$ & $8,01^{\mathrm{a}}$ & $7,94^{\mathrm{a}}$ & $6,78^{\mathrm{b}}$ & 7,74 & 0,21 & $<0,001$ & 0,010 \\
\hline $\mathrm{NDT}^{10}$ & $14,20^{\mathrm{a}}$ & $13,84^{\mathrm{a}}$ & $13,73^{\mathrm{a}}$ & $11,77^{\mathrm{b}}$ & 13,38 & 0,35 & $<0,001$ & 0,003 \\
\hline \multicolumn{9}{|c|}{ Consumo \% PV } \\
\hline $\mathrm{MS}^{3}$ & $3,70^{\mathrm{a}}$ & $3,64^{\mathrm{a}}$ & $3,60^{\mathrm{a}}$ & $3,04^{b}$ & 3,50 & 0,06 & $<0,001$ & $<0,001$ \\
\hline $\mathrm{FDN}^{8}$ & $1,17^{\mathrm{a}}$ & $1,16^{\mathrm{a}}$ & $1,15^{\mathrm{a}}$ & $0,96^{\mathrm{b}}$ & 1,11 & 0,02 & $<0,001$ & $<0,001$ \\
\hline
\end{tabular}

${ }^{1}$ Controle (C); M12, M24 e M48, inclusão de 12, 24 e $48 \mathrm{mg} / \mathrm{kg}$ de MS de monensina sódica na dieta total, respectivamente. ${ }^{2}$ Probabilidades de resposta linear (L) ou quadrática (Q). Médias seguidas de letras diferentes nas linhas se diferenciam em 5\% no teste de TUKEY ajustado pelo PROC MIXED. ${ }^{3} \mathrm{MS}$ (matéria seca); ${ }^{4} \mathrm{MO}$ (matéria orgânica); ${ }^{5} \mathrm{~PB}$ (proteína bruta); ${ }^{6} \mathrm{EE}$ (extrato etéreo); ${ }^{7} \mathrm{CT}$ (carboidratos totais); ${ }^{8} \mathrm{FDN}$ (fibra em detergente neutro); ${ }^{9} \mathrm{CNF}$ (carboidrato não fibroso); ${ }^{10} \mathrm{NDT}$ (nutrientes digestíveis totais). 
Analisando 14 estudos onde vacas em lactação foram suplementadas com monensina sódica em dosagens acima de $35 \mathrm{mg} / \mathrm{kg}$ de MS da dieta total, houve redução média no consumo de matéria seca de $0,33 \mathrm{~kg} /$ dia, o que representou redução de $1,5 \%$ no consumo dos animais do grupo monensina (IPHARRAGUERRE ; CLARK, 2003). Gandra et. al. (2009), a utilização de monensina sódica nas rações ocasionou redução do consumo de matéria seca, que em média, reduziu 2,94\% e 12,42\% nas rações com 24 e 48 mg/kg de monensina sódica, respectivamente, em relação à ração controle.

Duffield et al. (2008) avaliaram os efeitos da monensina sódica no consumo de matéria seca, e concluiram que a adição deste suplemento diminuiu o consumo em média 0,30 kg/dia quando comparado com a ração controle. Em estudo realizado por Eifert et al. (2005), utilizando dose de $16 \mathrm{mg} / \mathrm{kg}$ MS de monensina sódica, foi observada redução no consumo de matéria seca de apenas $1,4 \%$ em relação à ração controle.

Symanowski et al. (1999) utilizaram monensina na concentração de 0, 8, 16 e 24 mg/kg MS e observaram redução de consumo nos dois últimos níveis avaliados. De forma similar, McClary et al. (2005) avaliaram diferentes doses de monensina (0, 7, 15 e $22 \mathrm{mg} / \mathrm{kg}$ MS) para vacas leiteiras e observaram que nos dois últimos níveis de utilização, houve redução de consumo.

No entanto, Martineau et al. (2007), que avaliaram vacas no terço médio de lactação com dose de $24 \mathrm{mg} / \mathrm{kg}$ MS de monensina, não encontraram diferenças no consumo quando compararam estes animais com o grupo controle. Outros autores, como Ramanzin et al. (1997) e Petersson-Wolfe et al. (2007), utilizando doses de 22 e $15 \mathrm{mg} / \mathrm{kg}$ MS de monensina, respectivamente, obtiveram resultados semelhantes.

A utilização de 16 a $24 \mathrm{mg} / \mathrm{kg}$ MS de monensina sódica nas rações de vacas leiteiras no terço médio de lactação parece ser a dose limitante de fornecimento onde pode haver alguma alteração no consumo. Doses acima de $35 \mathrm{mg} / \mathrm{kg}$ MS de monensina se relacionam 
com forte redução de consumo em vacas no terço médio da lactação. Não está completamente claro na literatura o efeito das doses de monensina associadas a diferentes rações basais ou diferentes volumosos.

\subsection{DIGESTIBILIDADE APARENTE TOTAL}

Os resultados de digestibilidade aparente total da matéria seca e dos nutrientes podem ser observados na (Tabela 6). Não houve diferença $(\mathrm{P}>0,05)$ na digestibilidade aparente total da matéria seca, matéria orgânica, extrato etéreo, carboidratos não fibrosos carboidratos totais, e nos valores de nutrientes digestíveis totais observados para as rações experimentais.

Houve efeito linear crescente $(\mathrm{P}<0,05)$ na digestibilidade aparente total da proteína bruta e efeito linear decrescente de fibra em detergente neutro. Este resultado em relação à digestibilidade aparente total da proteína pode ser explicado pela modificação que a suplementação com monensina imprime no metabolismo do nitrogênio ruminal. Na dose correta este ionóforo pode reduzir as concentrações de nitrogênio amoniacal pela redução da deaminação da proteína, desta forma pode contribuir para com o aumento da quantidade de proteína verdadeira que chega ao intestino delgado, melhorando a digestibilidade aparente total da proteína. O efeito na fibra de detergente neutro pode ser explicado pelo fato de a monesina sódica alterar a fermentação ruminal e as bactérias gram positivas que influenciam na digestibilidade de fibras em detergente neutro. 
Tabela 6 - Efeito das rações experimentais sobre a digestibilidade aparente total da matéria seca e nutrientes

\begin{tabular}{|c|c|c|c|c|c|c|c|c|}
\hline \multirow{2}{*}{ Variáveis } & \multicolumn{4}{|c|}{ Dietas experimentais $^{1}$} & \multirow{2}{*}{ Média } & \multirow{2}{*}{ EPM } & \multicolumn{2}{|c|}{$\overline{\mathrm{P}^{2}}$} \\
\hline & $\mathrm{C}$ & M12 & M24 & M48 & & & $\overline{\mathrm{L}}$ & $\mathrm{Q}$ \\
\hline \multicolumn{9}{|c|}{ Digestibilidade aparente total\% } \\
\hline CDMS & 67,45 & 67,74 & 67,49 & 67,27 & 67,48 & 0,33 & 0,789 & 0,692 \\
\hline CDMO & 69,07 & 70,44 & 70,36 & 69,39 & 69,81 & 0,33 & 0,820 & 0,178 \\
\hline CDPB & $69,78^{\mathrm{a}}$ & $72,78^{\mathrm{ab}}$ & $73,34^{\mathrm{ab}}$ & $74,56^{\mathrm{b}}$ & 72,61 & 0,68 & 0,003 & 0,426 \\
\hline CDEE & 88,67 & 90,39 & 89,13 & 89,87 & 89,51 & 0,34 & 0,462 & 0,491 \\
\hline CDCT & 67,41 & 66,82 & 66,67 & 66,16 & 66,76 & 0,39 & 0,248 & 0,953 \\
\hline CDFDN & $55,16^{\mathrm{a}}$ & $52,50^{\mathrm{ab}}$ & $52,51^{\mathrm{ab}}$ & $50,28^{\mathrm{b}}$ & 52,61 & 0,87 & 0,017 & 0,868 \\
\hline CDCNF & 68,30 & 71.09 & 70,26 & 72,20 & 70,46 & 0,84 & 0,052 & 0,722 \\
\hline $\mathrm{NDT}_{\mathrm{OBS}}$ & 69,81 & 70,43 & 69,87 & 71,32 & 70,35 & 0,46 & 0,327 & 0,647 \\
\hline \multicolumn{9}{|c|}{ Comsumo em \% PV } \\
\hline FDN & $1,19^{\mathrm{a}}$ & $1,16^{\mathrm{a}}$ & $1,15^{\mathrm{a}}$ & $0,98^{\mathrm{b}}$ & 1,12 & 0,02 & $<0,001$ & 0,026 \\
\hline MS & $3,67^{\mathrm{a}}$ & $3,57^{\mathrm{a}}$ & $3,54^{\mathrm{a}}$ & $3,01^{\mathrm{b}}$ & 3,44 & 0,06 & $<0,001$ & 0,005 \\
\hline
\end{tabular}

${ }^{\mathrm{T}}$ Controle (C); M12, M24 e M48, inclusão de 12, 24 e $48 \mathrm{mg} / \mathrm{kg}$ de MS de monensina sódica na dieta total, respectivamente. ${ }^{2}$ Probabilidades de resposta linear (L) ou quadrática (Q). Médias seguidas de letras diferentes nas linhas se diferenciam em 5\% no teste de TUKEY ajustado pelo PROC MIXED.

Oelker et al. (2009) utilizando dose de $17 \mathrm{mg} / \mathrm{kg}$ de MS de monensina sódica em vacas em lactação com silagem de milho como volumoso também não encontraram efeito na digestibilidade aparente total da matéria seca e dos nutrientes. Porém, os mesmos autores encontraram valores maiores para o coeficiente de digestibilidade aparente total da proteína, de $77,50 \%$, e menor para o da fibra em detergente neutro, de $48,50 \%$.

Da Silva et al. (2008) e Gehman et al. (2008), suplementando vacas no terço médio de lactação com 20 e 16 mg/kg MS de monensina sódica, respectivamente, tendo a silagem de milho como volumoso, também não observaram efeito da suplementação de monensina sobre a digestibilidade aparente total da matéria seca e dos nutrientes, reforçando a influência do período de lactação influenciando na digestibilidade aparente total em rações suplementadas com monensina.

Gandra (2009), em experimento com vacas Holandesas em terço médio de lactação, suplementadas com monensina sódica nas concentrações de 0,24 e $48 \mathrm{mg} / \mathrm{Kg}$ de $\mathrm{MS}$, não foi observado efeito na excreção total de fezes, na digestibilidade aparente total da matéria seca, matéria orgânica, proteína bruta, extrato etéreo, fibra em detergente neutro, 
carboidratos não fibrosos carboidratos totais, e nos valores de nutrientes digestíveis totais observados para as rações experimentais.

Osborne et al. (2004) suplementando vacas no terço médio de lactação, com 22 mg/kg MS de monensina sódica, também fazendo uso da silagem de milho como volumoso, observaram aumento da digestibilidade da fibra em detergente neutro de $16,4 \%$ em relação ao controle.

Em relação aos coeficientes de digestibilidade aparente total dos carboidratos não fibrosos e carboidratos totais, Eifert et al. (2005) ao suplementarem vacas no inicio de lactação com 16 mg/kg MS de monensina por dia o encontraram valores de 86,00 e 70,85\%, respectivamente, resultados semelhantes aos do presente estudo, apesar de não observarem efeito $(\mathrm{P}>0,05)$ sobre os parâmetros de digestibilidade.

\subsection{FERMENTAÇÃO RUMINAL}

Não houve efeito $(\mathrm{P}>0,05)$ dos níveis de monensina sódica utilizados sobre os valores de pH ruminal três horas após a alimentação da manhã (Tabela 7). Os valores de pH ruminal mostraram-se mais elevados em relação aos dados da literatura, sendo este resultado provavelmente relacionado ao efeito das rações combinado ao período de lactação em que esses animais se encontravam no período experimental.

De forma semelhante, não houve efeito $(\mathrm{P}>0,05)$ dos níveis de monensina sódica utilizados nas rações sobre os valores de nitrogênio amoniacal ruminal no tempo avaliado. Os valores de nitrogênio amoniacal obtidos mostraram-se semelhantes a dados citados na 
literatura para vacas submetidas a rações contendo monensina sódica e para vacas no terço médio de lactação (IPHARRAGUERRE ; CLARK, 2003).

Martineau et al. (2007) observaram valores de 6,16 e 17,7 mg/dl para $\mathrm{pH}$ ruminal e nitrogênio amoniacal, respectivamente, em dietas com $24 \mathrm{mg} / \mathrm{kg}$ de $\mathrm{MS}$ de monensina sódica. Esses resultados diferem dos encontrados neste trabalho, principalmente pela diferença de nível de produção de leite, consumo de matéria seca e formulação de rações entre os estudos. Os resultados obtidos neste estudo, com a utilização de níveis de monensina sódica as rações de até $48 \mathrm{mg} / \mathrm{kg}$ MS, não influenciaram negativamente os parâmetros de fermentação ruminal, mesmo quando houve redução de consumo.

Tabela 7-Médias ajustadas e erro padrão da média (EPM) do $\mathrm{pH}$, concentrações de nitrogênio amoniacal $\left(\mathrm{N}-\mathrm{NH}_{3}\right)$, proporção e concentração molar e total de ácidos graxos de cadeia curta (AGCC) no líquido ruminal, três horas após a alimentação, segundo as rações experimentais

\begin{tabular}{|c|c|c|c|c|c|c|c|c|}
\hline \multirow[b]{2}{*}{ Variáveis } & \multicolumn{4}{|c|}{ Rações experimentais ${ }^{1}$} & \multirow[b]{2}{*}{ Média } & \multirow[b]{2}{*}{$\mathrm{EPM}^{2}$} & \multicolumn{2}{|c|}{$\mathrm{P}^{2}$} \\
\hline & $\mathrm{C}$ & M12 & M24 & M48 & & & $\mathrm{L}$ & Q \\
\hline $\mathrm{Ph}$ & 6,54 & 6,61 & 6,60 & 6,48 & 6,56 & 0,04 & 0,606 & 0,241 \\
\hline $\mathrm{N}-\mathrm{NH}_{3}(\mathrm{mg} / \mathrm{dL})$ & 17,24 & 18,36 & 18,27 & 18,72 & 19,28 & 0,86 & 0,479 & 0,804 \\
\hline Total AGCC mM & 103,91 & 98,74 & 101,13 & 100,68 & 101,12 & 2,37 & 0,706 & 0,586 \\
\hline Acetato & 68,99 & 64,34 & 63,76 & 62,29 & 64,85 & 1,63 & 0,118 & 0,585 \\
\hline Propionato & $24,08^{\mathrm{b}}$ & $24,27^{\mathrm{b}}$ & $26,97^{\mathrm{ab}}$ & $29,57^{\mathrm{a}}$ & 26,22 & 0,98 & 0,004 & 0,380 \\
\hline Butirato & 10,83 & 10,13 & 10,40 & 8,81 & 10,04 & 0,37 & 0,045 & 0,320 \\
\hline \multicolumn{9}{|c|}{ Total AGCC \% } \\
\hline Acet: & $66,54^{\mathrm{a}}$ & $65,01^{\mathrm{ab}}$ & $63,26^{\mathrm{bc}}$ & $61,80^{\mathrm{c}}$ & 64,15 & 0,66 & $<0,001$ & 0,959 \\
\hline Propionato & $23,00^{\mathrm{c}}$ & $24,90^{\mathrm{bc}}$ & $26,51^{\mathrm{ab}}$ & $29,43^{\mathrm{a}}$ & 25,96 & 0,76 & $<0,001$ & 0,611 \\
\hline Butirato & $10,45^{\mathrm{a}}$ & $10,09^{\mathrm{ab}}$ & $10,22^{\mathrm{a}}$ & $8,76^{\mathrm{b}}$ & 9,88 & 0,25 & 0,004 & 0,133 \\
\hline $\mathrm{A} / \mathrm{P}$ & $3,00^{\mathrm{a}}$ & $2,75^{\mathrm{a}}$ & $2,55^{\mathrm{ab}}$ & $2,14^{\mathrm{b}}$ & 2,61 & 0,10 & $<0,001$ & 0,579 \\
\hline
\end{tabular}

${ }^{1}$ Controle (C); M12, M24 e M48, inclusão de 12, 24 e $48 \mathrm{mg} / \mathrm{kg}$ de MS de monensina sódica na dieta total, respectivamente. ${ }^{2}$ Probabilidades de resposta linear (L) ou quadrática (Q). Médias seguidas de letras diferentes nas linhas se diferenciam em 5\% no teste de TUKEY ajustado pelo PROC MIXED.

Em relação a produção de ácidos graxos de cadeia curta (Tabela 5), a suplementação com monensina sódica nas dietas resultou em alteração da proporção molar de propionato no líquido ruminal $(\mathrm{P}<0,05)$, além de diminuir a relação acetato:proprionato $(\mathrm{P}<0,05)$. As rações contendo monensina sódica apresentaram maior proporção molar de proprionato e 
menor de acetato em relação a ração controle, e, de forma semelhante, apresentaram menor relação acetato:propionato.

Gandra (2009), em experimento suplementando vacas leiteiras com monensina sódica nas concentrações de 0,24 e $48 \mathrm{mg} / \mathrm{Kg}$ de $\mathrm{MS}$, houve redução na porcentagem e concentração molar dos ácidos acético e butírico, bem como para a relação acetato/propionato. Foi observado desvio da linearidade para a porcentagem e concentração molar do ácido propiônico, sendo as maiores concentrações encontradas para a ração M24. Comportamento semelhante foi observado para a concentração total de ácidos graxos de cadeia curta.

Com a utilização de ionóforos na alimentação de ruminantes, há uma redução da população de bactérias gram positivas que produzem o ácido acético e butírico; isto favorece o crecimento de bactérias gram negativas resistentes a monensina que produzem o ácido propiônico (DUFFIELD ; BAGG, 2000).

Segundo Russell e Strobel (1989), a utilização da suplementação com monensina sódica na ração de vacas leiteiras resulta em aumento da produção do ácido propiônico, e redução da relação de acetato:propionato, sendo portanto, efeito esperado. Estes resultados são semelhantes também aos verificados na revisão de literatura realizada por Ipharraguere e Clark (2003).

A utilização de monensina sódica nas rações de vacas em lactação influenciam o ambiente ruminal, os processos digestivos e o desempenho produtivo, sendo estes efeitos dependentes da dose utilizada nas rações. 


\subsection{SÍNTESE DE PROTEÍNA MICROBIANA}

Não houve efeito $(\mathrm{P}>0,05)$ das rações utilizadas nas excreções diárias totais de urina, de alantoína e de acido úrico na urina, e de derivados de purinas totais. Não houve diferença $(\mathrm{P}>0,05)$ na porcentagem de alantoína nos derivados de purina, das purinas absorvidas e do nitrogênio microbiano para as rações experimentais (Tabela 8). Houve efeito linear decrescente $(\mathrm{P}<0,05)$ nas concentrações de alantoína no leite, que pode ser explicado pela produção de leite que também foi observado efeito linear decrescente.

Os resultados encontrados podem estar relacionados com o nível de produção dos animais, pois como os animais se mantiveram em mesma faixa de produção de leite, possivelmente a taxa de passagem da digesta foi extremamente semelhante entre as dietas. Em taxas de passagem semelhantes, a idade média dos microrganismos é a mesma (Van Soest, 1984), selecionando microrganismos com mesmo tempo de geração e mesmo de utilização de substratos para mantença microbiana. Assim, a produção de proteína microbiana será também semelhante. Os resultados encontrados neste estudo estão de acordo com Chizzotti (2004).

Gandra (2009), em experimento com doses de 0, 24 e $48 \mathrm{mg} / \mathrm{Kg}$ de MS de monensina sódica, também não encontrou efeito $(\mathrm{P}>0,05)$ das rações utilizadas nas excreções diárias totais de urina, de alantoína e de acido úrico na urina, de alantoína no leite, derivados de purinas totais, na porcentagem de alantoína nos derivados de purina, das purinas absorvidas e do nitrogênio microbiano para as rações experimentais. Porém encontrou efeito da eficiência de síntese microbiana ruminal para as rações experimentais que contém monensina sódica. Este resultado está intimamente relacionado com os efeitos da monensina sobre o consumo de matéria seca e eficiência produtiva. 
Tabela 8- Médias e erro padrão da média (EPM) das concentrações de alantoína na urina (AL-urina) e do ácido úrico, concentrações de alantoína no leite (ALAL), as purinas microbianas absorvidas (Pabs), da alantoína em porcentagem das purinas totais (ALA:DP), da excreção total de urina (ETU), do nitrogênio microbiano (Nmic) e da eficiência de síntese de proteína microbiana, em função das rações experimentais

\begin{tabular}{|c|c|c|c|c|c|c|c|c|}
\hline \multirow{2}{*}{ Variáveis } & \multicolumn{4}{|c|}{ Rações experimentais 1} & \multirow{2}{*}{ Média } & \multirow[t]{2}{*}{ EPM } & \multicolumn{2}{|c|}{$P^{2}$} \\
\hline & $\mathrm{C}$ & M12 & M24 & M48 & & & $\mathrm{L}$ & Q \\
\hline \multicolumn{9}{|c|}{ Mmol/dia } \\
\hline Alantoina & 386,52 & 335,85 & 334,85 & 334,93 & 348,03 & 24,43 & 0,133 & 0,914 \\
\hline Acido Úrico & 53,51 & 55,51 & 45,68 & 43,13 & 49,45 & 4,45 & 0,284 & 0,788 \\
\hline $\mathrm{ALAL}^{3}$ & $1,13^{\mathrm{ab}}$ & $1,15^{\mathrm{a}}$ & $1,13^{\mathrm{ab}}$ & $1,07^{\mathrm{b}}$ & 1,12 & 0,03 & 0,029 & 0,087 \\
\hline $\mathrm{DP}^{4}$ & 440,12 & 391,50 & 380,74 & 336,33 & 387,17 & 26,51 & 0,122 & 0,963 \\
\hline $\mathrm{Pabs}^{5}$ & 501,08 & 443,15 & 430,29 & 377,57 & 438,02 & 31,53 & 0,122 & 0,961 \\
\hline ALA: DP $(\%)$ & 85,58 & 85,45 & 87,75 & 86,64 & 86,35 & 1,07 & 0,481 & 0,777 \\
\hline ETU (L/dia) & 21,34 & 20,60 & 21,49 & 21,96 & 21,34 & 0,85 & 0,601 & 0,609 \\
\hline Nmic (g/dia) & 315,39 & 278,91 & 270,81 & 237,63 & 275,68 & 19,84 & 0,122 & 0,961 \\
\hline Eficiência & 151,90 & 127,72 & 133,63 & 114,54 & 131,94 & 9,89 & 0,175 & 0,882 \\
\hline
\end{tabular}

${ }^{\mathrm{C}}$ Controle (C); M12, M24 e M48, inclusão de 12, 24 e $48 \mathrm{mg} / \mathrm{Kg}$ de MS de Monensina sódica na dieta total, respectivamente; ${ }^{2}$ Probabilidades de resposta linear (L) ou quadrática (Q). Médias seguidas de letras diferentes nas linhas se diferenciam em 5\% no Teste de Tukey ajustado pelo PROC MIXED. ${ }^{3}$ alantoína no leite; ${ }^{4}$ derivados de purinas.

Gehman et al. (2008) suplementaram vacas leiteiras no terço médio de lactação com $16 \mathrm{mg} / \mathrm{kg}$ MS de monensina e também não observaram efeito da monensina sobre a produção total de purinas e a produção de proteína microbiana, porém os valores de $297,6 \mathrm{mmol} /$ dia e $1.168 \mathrm{~g} /$ dia, respectivamente, para produção de purinas totais e produção de proteína microbiana, reportados por estes autores, são inferiores aos observados neste estudo.

Contrariamente, Eifert et al. (2005) observaram efeito negativo $(\mathrm{P}<0,05) \mathrm{em}$ relação à produção de nitrogênio microbiano, e nenhum efeito sobre a eficiência da produção de proteína microbiana, quando suplementaram vacas no início da lactação com 16 mg/kg MS. O valor de 227,1 g/dia observado por Eifert et al. (2005) em relação à produção de nitrogênio microbiano foi superior ao relatado neste estudo, resultado este explicado pela diferença no período de lactação em que os animais se encontravam nos dois experimentos. 


\subsection{BALANÇO DE ENERGIA E NITROGÊNIO}

Houve efeito linear decrescente $(\mathrm{P}<0,05)$ para os valores de energia bruta, energia digestível e energia líquida de lactação (Tabela 9), que podem ser explicados pelo fato de também ocorrer efeito linear decrescente no consumo de matéria seca.

Houve também efeito linear decrescente $(\mathrm{P}<0,05)$ para energia líquida para produção de leite, mudança de peso de corpo vazio e energia líquida de ganho, pelo fato que à medida que foi aumentando o nível de monensina sódica, foi diminuindo o ganho de peso e os animais foram utilizando reservas corporais para produção de leite, pelo fato de haver redução no consumo de matéria seca.

O balanço de energia diminuiu à medida que foi aumentando o nível de monensina sódica.

Esse modelo de cálculo de balanço de energia foi escolhido por eliminar os erros de aumento de ganho de peso vivo que podem superestimar o aumento nas exigências de mantença (HARVATINE ; ALLEN, 2006). O peso metabólico pode ser usado para predizer as exigências de energia de mantença entre animais diferindo no peso vivo, mas não estimar as mudanças nas exigências de energia líquida de mantença com ganho de peso, pois há variações na composição corporal dos animais estudados (NRC, 2001).

Gandra (2009) em experimento com doses de 0, 24 e $48 \mathrm{mg} / \mathrm{Kg}$ de $\mathrm{MS}$, relatou efeito das rações experimentais para o consumo de energia bruta, digestível, metabolizável e líquida e para produção de energia líquida de ganho. linearidade $(\mathrm{P}<0,05)$ para a produção de energia líquida de lactação e para o balanço de energia, com os maiores valores observados para a ração M24, indicando possivelmente que a dose de $24 \mathrm{mg} / \mathrm{kg}$ de $\mathrm{MS}$ de monensina sódica seja a mais adequada para vacas no terço médio de lactação. 
Tabela 9 - Eficiência de utilização e balanço de energia em função das rações experimentais

\begin{tabular}{|c|c|c|c|c|c|c|c|c|}
\hline \multirow{2}{*}{ Variáveis } & \multicolumn{4}{|c|}{ Rações experimentais ${ }^{1}$} & \multirow{2}{*}{ Média } & \multirow[t]{2}{*}{ EPM } & \multicolumn{2}{|c|}{$\overline{P^{2}}$} \\
\hline & $\mathrm{C}$ & M12 & M24 & M48 & & & $\mathrm{L}$ & Q \\
\hline \multicolumn{9}{|c|}{ Consumo (Mcal/dia) } \\
\hline $\mathrm{EB}^{3}$ & $79,19^{\mathrm{a}}$ & $77,24^{\mathrm{a}}$ & $76,99^{\mathrm{a}}$ & $63,77^{\mathrm{b}}$ & 74,29 & 1,84 & $<0,001$ & $<0,001$ \\
\hline $\mathrm{ED}^{4}$ & $52,86^{\mathrm{a}}$ & $51,72^{\mathrm{a}}$ & $51,23^{\mathrm{a}}$ & $42,60^{\mathrm{b}}$ & & 9 & 0,001 & 0,003 \\
\hline $\mathrm{EL}_{\mathrm{L}}^{5}$ & $38,38^{\mathrm{a}}$ & $37,52^{\mathrm{a}}$ & $37,36^{\mathrm{a}}$ & $31,21^{\mathrm{b}}$ & 30,11 & 0,83 & $<0,001$ & $<0,001$ \\
\hline \multicolumn{9}{|c|}{ Produção } \\
\hline $\mathrm{EL}_{\mathrm{L}}^{6}(\mathrm{Mcal} / \mathrm{dia})$ & $19,17^{\mathrm{a}}$ & $18,47^{\mathrm{a}}$ & $18,60^{\mathrm{a}}$ & $15,78^{b}$ & 18,00 & 0,54 & 0,002 & 0,136 \\
\hline g/dia) & $0,42^{\mathrm{a}}$ & $0,33^{\mathrm{a}}$ & $-0,06^{\mathrm{ab}}$ & $-0,37^{b}$ & & 0 , & $<0,001$ & 0,465 \\
\hline $\operatorname{ELg}^{7}(g)$ & $10,09^{\mathrm{a}}$ & $9,94^{\mathrm{a}}$ & $9,68^{a b}$ & $6,46^{\mathrm{b}}$ & 4 & 0,58 & 0,006 & 0,081 \\
\hline \multicolumn{9}{|c|}{ Balanço de energia } \\
\hline $\mathrm{EL}^{8}$ & 9,11 & 9,10 & 9,07 & 8,96 & 06 & 0,08 & 0,045 & 0,303 \\
\hline \multicolumn{9}{|c|}{ Eficiência energética } \\
\hline $\mathrm{EL}_{\mathrm{P}}{ }^{9} / \mathrm{CED}$ & 0,55 & 0,54 & 0,55 & 0,51 & 0,54 & 0,01 & $<0,001$ & 0,192 \\
\hline $\mathrm{EL}_{\mathrm{L}} / \mathrm{CED}$ & 0,36 & 0,35 & 0,37 & 0,37 & 0,36 & 0,01 & 0,623 & 0,902 \\
\hline
\end{tabular}

${ }^{1}$ Controle (C); M12, M24 e M48, inclusão de 12, 24 e $48 \mathrm{mg} / \mathrm{Kg}$ de MS de Monensina sódica na dieta total, respectivamente. ${ }^{2}$ Probabilidades de resposta linear (L) ou quadrática (Q). Médias seguidas de letras diferentes nas linhas se diferenciam em 5\% no Teste de Tukey ajustado pelo PROC MIXED. ${ }^{3}$ Consumo de energia bruta (ceb); ${ }^{4}$ Consumo de energia digestível (ced); ${ }^{5} \mathrm{ELl}$ (consumo) $=0.703 \times \mathrm{EM}$ (consumo) $-0.19+$ $\{[(0.097 \times \mathrm{EM}($ consumo $)+0.19) / 97] \times[\mathrm{EE}-3]\} ;{ }^{6} \mathrm{ELl}$ para produção de leite $(\mathrm{mcal} / \mathrm{dia})=$ produção de leite $(\mathrm{kg}) \times\left(0.0929 \times \mathrm{g} \%+0.0563 \times\right.$ proteína verdadeira \% $+0.0395 \times$ lactose\%) $(\mathrm{NRC}, 2001) .{ }^{7} \mathrm{ELg}($ variação de peso corporal) calculado pelas fórmulas do nrc (2001). ${ }^{8} \mathrm{ELp}=\mathrm{EL}$ (consumo) - EL (ganho pv) - EL (leite). ${ }^{9} \mathrm{ELl}$ para desempenho de lactação $=($ EL produção de leite + EL ganho de pv $)$.

Houve efeito linear decrescente $(\mathrm{P}<0,05)$ para os valores de nitrogênio total (Tabela 10), que pode ser explicado pelo fato de também ter efeito linear decrescente no consumo de proteína bruta. De forma coerente, o nitorgênio nas fezes, nitrogênio na urina e nitrogênio no leite, também sofreu efeito linear decrescente.

Foi observado efeito $(\mathrm{P}<0,05)$ das rações experimentais sobre a eficiência da utilização do nitrogênio, onde foram observados os melhores resultados nas rações suplementadas com monensina, possivelmente devido a melhor utilização do nitrogênio, em forma de aminoácidos disponível em nível intestinal decorrente das mudanças na fermentação ruminal provocada pela monensina (DUFFIELD et al., 2008).

Benchaar et al. (2006) não encontraram efeito sobre o balanço de nitrogênio quando suplementou vacas no início da lactação com $16 \mathrm{mg} / \mathrm{kg}$ MS de monensina. No entanto, encontrou o valor de $35 \mathrm{~g} /$ dia de nitrogênio retido, resultado este que se assemelha ao 
observado neste trabalho. As diferenças encontradas entre os dois estudos são devido ao período de lactação em que os animais se encontravam.

De maneira semelhante, Gehman et al. (2008) não observou efeito sobre o balanço de nitrogênio ao suplementarem vacas no terço médio de lactação com $16 \mathrm{mg} / \mathrm{kg} \mathrm{MS}$ de monensina. Porém encontrou um valor de 0,30 para eficiência de utilização de nitrogênio, resultado semelhante ao encontrado neste estudo.

O balanço de nitrogênio e a eficiência do uso do nitrogênio podem ser potencializados e melhorados com a suplementação de monensina sódica, porém, estes efeitos parecem ser dependentes do período de lactação, dose de monensina utilizada, bem como o nível de produção dos animais. Desta maneira, as implicações e recomendações a este respeito devem se criteriosas, levando em consideração os fatores acima descritos.

Tabela 10 - Médias e Erro padrão da média (EPM) dos compostos nitrogenados totais (NT), excreção de compostos nitrogenados nas fezes (N-fezes), na urina (N-urina) e leite (N-leite), balanço de nitrogênio e eficiência da utilização de nitrogênio, em função das rações experimentais

\begin{tabular}{|c|c|c|c|c|c|c|c|c|}
\hline \multirow{2}{*}{ Variáveis } & \multicolumn{4}{|c|}{ Rações experimentais ${ }^{1}$} & \multirow{2}{*}{ Média } & \multirow[t]{2}{*}{ EPM } & \multicolumn{2}{|c|}{$\overline{P^{2}}$} \\
\hline & $\mathrm{C}$ & M12 & M24 & M48 & & & $\mathrm{L}$ & Q \\
\hline \multicolumn{9}{|c|}{ g/dia } \\
\hline NT & $625,47^{\mathrm{a}}$ & $614,13^{\mathrm{a}}$ & $610,77^{\mathrm{a}}$ & $502,58^{\mathrm{b}}$ & 588,23 & 14,69 & $<0,001$ & $<0,001$ \\
\hline N-fezes & $195,24^{\mathrm{a}}$ & $173,10^{\mathrm{a}}$ & $173,74^{\mathrm{a}}$ & $130,64^{b}$ & 168,17 & 6,93 & $<0,001$ & 0,099 \\
\hline $\mathrm{N}$-urina & 169,68 & 166,03 & 173,81 & 134,62 & 161,03 & 9,46 & 0,018 & 0,280 \\
\hline N-leite & $145,42^{\mathrm{a}}$ & $144,96^{\mathrm{a}}$ & $141,44^{\mathrm{a}}$ & $125,60^{b}$ & 139,35 & 3,65 & $<0,001$ & 0,032 \\
\hline Balanço N & 115,12 & 130,03 & 121,79 & 111,73 & 119,66 & 9,86 & 0,806 & 0,460 \\
\hline \multicolumn{9}{|c|}{$\% N T$} \\
\hline $\mathrm{N}$-fezes & $30,96^{\mathrm{a}}$ & $27,91^{\mathrm{a}}$ & $28,18^{\mathrm{a}}$ & $25,17^{\mathrm{b}}$ & 28,06 & 0,68 & $<0,001$ & 0,980 \\
\hline $\mathrm{N}$-urina & 27,34 & 27,35 & 28,97 & 27,80 & 27,87 & 1,68 & 0,821 & 0,841 \\
\hline N-leite & 23,32 & 23,61 & 23,39 & 25,19 & 23,88 & 0,43 & 0,078 & 0,260 \\
\hline Balanço & 18,36 & 21,11 & 19,43 & 21,81 & 20,18 & 1,62 & 0,504 & 0,949 \\
\hline Eficiência $^{3}$ & 0,233 & 0,236 & 0,234 & 0,232 & 0,23 & 0,01 & 0,083 & 0,259 \\
\hline
\end{tabular}

${ }^{1}$ Controle (C); M12, M24 e M48, inclusão de 12, 24 e $48 \mathrm{mg} / \mathrm{Kg}$ de MS de Monensina sódica na dieta total, respectivamente. ${ }^{2}$ Probabilidades de resposta linear (L) ou quadrática (Q). Médias seguidas de letras diferentes nas linhas se diferenciam em 5\% no Teste de Tukey ajustado pelo PROC MIXED. ${ }^{3} \mathrm{~kg} \mathrm{~N}$ leite $/ \mathrm{kg}$ de N ingerido. 


\subsection{PRODUÇÃO E COMPOSIÇÃO DO LEITE}

Foi observado aumento de produção de leite $(\mathrm{P}<0,05)$ para as vacas alimentadas com os níveis intermediários de monensina sódica nas rações. No entanto, analisando a comparação das médias ajustadas verifica-se que somente no maior nível de utilização de monensina, $48 \mathrm{mg} / \mathrm{kg}$ MS, foi observada redução da produção de leite em relação as demais dietas experimentais. Não foi verificado diferença entre a dieta controle e as dietas com 12 e $24 \mathrm{mg} / \mathrm{kg}$ MS em relação ao desempenho produtivo das vacas (Tabela 11).

Foi observado aumento linear da eficiência produtiva $(\mathrm{P}<0,05)$, onde o menor consumo e a maior produção de leite para as rações contendo monensina sódica justificam este resultado. A dieta que apresentou a melhor eficiência produtiva, apesar de grande redução de consumo e produção de leite, foi a ração com 48 ppm/kg de MS (M48).

Houve efeito da utilização de monensina sódica nas rações sobre a produção de gordura no leite, resultou em diminuição linear $(\mathrm{P}<0,05)$. No entanto, analisando a comparação das medias ajustadas verifica-se que somente no maior nível de utilização de monensina, $48 \mathrm{mg} / \mathrm{kg} \mathrm{MS}$, foi observado menor valor para a produção de gordura, sem diferença entre os tratamentos (Tabela 9). Não houve efeito das rações experimentais utilizadas sobre o peso corporal, escore e mudança de escore de condição corporal.

As vacas submetidas à ração M48 apresentaram menor produção de leite e de seus componentes em relação às demais rações experimentais. No entanto, apesar de apresentar menor produção de leite e menor consumo do que as demais rações utilizadas, este grupo apresentou a melhor eficiência produtiva $(\mathrm{P}<0,05)$.

Foi observado efeito linear crescente $(\mathrm{P}<0,05)$ nos teores de uréia e nitrogênio uréico no leite. Esses resultados estão coerentes com o aumento da uréia plasmática, o que pode indicar que o aumento da digestibilidade da proteína proporcionou maior metabolização 
hepática de compostos nitrogenados, e conseqüentemente maior formação de uréia. De acordo com o balanço de nitrogênio do presente trabalho, houve menor excreção de nitrogênio nas fezes e na urina, o que justifica o aumento das concentrações de uréia no leite a qual foi a via de excreção utilizada, pois também ocorreu uma maior excreção de nitrogênio no leite em porcentagem de nitrogênio total (Tabela 10).

Tabela 11 - Médias e erro padrão da média (EPM) da produção diária de leite, sem (PL) e com correção para 3,5\% de gordura (PLC), teores e produção diária no leite de gordura, proteína bruta, uréia (URL), nitrogênio uréico no leite (NUL), peso corporal, eficiência produtiva (EP), escore de condição corporal (ECC) e mudança de escore de condição corporal (MECC), em função das rações experimentais

\begin{tabular}{|c|c|c|c|c|c|c|c|c|}
\hline \multirow{2}{*}{ Variáveis } & \multicolumn{4}{|c|}{ Rações experimentais $^{1}$} & \multirow{2}{*}{ Média } & \multirow[t]{2}{*}{ EPM } & \multicolumn{2}{|l|}{$P^{2}$} \\
\hline & Controle & M12 & M24 & M48 & & & $\mathrm{L}$ & Q \\
\hline \multicolumn{9}{|c|}{$\mathrm{kg} / \mathrm{dia}$} \\
\hline PL & $31,47^{\mathrm{a}}$ & $31,93^{\mathrm{a}}$ & $31.62^{\mathrm{a}}$ & $28,78^{\mathrm{b}}$ & 30,95 & 0,84 & $<0,001$ & 0.001 \\
\hline PLC & $27,76^{\mathrm{a}}$ & $26,97^{\mathrm{ab}}$ & $27,00^{\mathrm{ab}}$ & $23,28^{\mathrm{b}}$ & 26,25 & 0,78 & 0,011 & 0,193 \\
\hline Gordura & 0,86 & 0,81 & 0,83 & 0,67 & 0,79 & 0,03 & 0,048 & 0,444 \\
\hline Proteína bruta & $0,92^{\mathrm{a}}$ & $0,94^{\mathrm{a}}$ & $0,91^{\mathrm{a}}$ & $0,83^{\mathrm{b}}$ & 0,90 & 0,02 & 0,002 & 0,023 \\
\hline \multicolumn{9}{|c|}{$\%$} \\
\hline Proteína bruta & 2,96 & 2,97 & 2,93 & 2,90 & 2,94 & 0,03 & 0,339 & 0,672 \\
\hline Gordura & 2,81 & 2,60 & 2,65 & 2,34 & 2,60 & 0,10 & 0,133 & 0,807 \\
\hline \multicolumn{9}{|c|}{$M g / d l$} \\
\hline URL & 20,87 & 20,77 & 21,18 & 23,00 & 21,45 & 0,61 & 0,036 & 0,181 \\
\hline NUL & 9,75 & 9,70 & 9,89 & 10,74 & 10,02 & 0,28 & 0,036 & 0,182 \\
\hline \multicolumn{9}{|c|}{$K g$} \\
\hline Peso corporal & 547,21 & 547,73 & 550,60 & 545,80 & 547,84 & 6,59 & 0,912 & 0,346 \\
\hline $\mathrm{EP}^{3}$ & $1,55^{\mathrm{b}}$ & $1,60^{\mathrm{b}}$ & $1,61^{b}$ & $1,72^{\mathrm{a}}$ & 1,62 & 0,03 & $<0,001$ & 0,207 \\
\hline ECC & 2,62 & 2,62 & 2,61 & 2,66 & 2,63 & 0,02 & 0,251 & 0,270 \\
\hline MECC & 0,02 & 0,03 & $-0,02$ & 0,02 & 0,01 & 0,02 & 0,716 & 0,725 \\
\hline
\end{tabular}

' Controle (C); M12, M24 e M48, inclusão de 12, 24 e $48 \mathrm{mg} / \mathrm{kg}$ de MS de monensina sódica na dieta total, respectivamente. ${ }^{2}$ Probabilidades de resposta linear (L) ou quadrática $(\mathrm{Q})$. Médias seguidas de letras diferentes nas linhas se diferenciam em $5 \%$ no teste de TUKEY ajustado pelo PROC MIXED. ${ }^{3}$ EP $=$ eficiência produtiva ( $\mathrm{kg}$ leite $/ \mathrm{kg}$ consumo).

Duffield et al. (2008) concluíram que a adição de monensina na ração de vacas leiteiras tem potencial para aumentar a produção de leite em $0,70 \mathrm{~kg} / \mathrm{dia}$, aumentando também a eficiência de produção de leite em $2,5 \%$, dados semelhantes aos obtidos no presente trabalho. Gallardo et al. (2006) também relataram efeito positivo da adição de 
monensina, aumentando a produção de leite em 4,0\% em relação à ração controle $(27,7$ vs. 26,6 kg/dia, respectivamente). Ramanzin et al. (1997), Zahra et al. (2006) e Martineau et al. (2007) não observaram efeito da adição de monensina sódica nas rações sobre a produção de leite de vacas em lactação.

Sauer et al. (1998) e Benchaar et al. (2006) reportaram redução no teor de gordura do leite e nenhuma mudança no teor de proteína quando suplementaram vacas em lactação com monensina. Entretanto, Ramanzin et al. (1997) observaram que a utilização de monensina não casou qualquer efeito no teor de gordura e proteína do leite. Os teores de gordura e proteína do leite diminuíram quando a monensina foi suplementada em vacas em lactação nos trabalhos de Phipps et al. (2000); Ruiz et al. (2001) e Broderick (2004). Em estudos nos quais a monensina reduziu os teores de gordura e proteína do leite paralelamente houve aumento expressivo na produção de leite, sugerindo assim que o efeito de diluição foi em parte responsável pelas mudanças na composição do leite (PHIPPS et al., 2000).

Não houve efeito da utilização das rações experimentais sobre o peso corporal, mudança de peso corporal, escore de condição corporal e mudança de escore de condição corporal $(\mathrm{P}>0,05)$. Estes resultados são diferentes de Duffield et al. (2008), onde a suplementação com monensina sódica aumentou em 0,03 pontos o escore de condição corporal e em $0,06 \mathrm{~kg} /$ dia o peso corporal em vacas em lactação. Diferenças de fase de lactação e nível de produção de leite nos animais avaliados entre o presente estudo e os citados por Duffield et al. (2008) provavelmente explicam estes resultados. 


\subsection{PARÂMETROS SANGUÍNEOS}

Não houve efeito $(\mathrm{P}>0,05)$ da adição de monensina sódica nas rações sobre os parâmetros sangüíneos glicose, colesterol total, proteína total, albumina, aspartato aminotransferase, $\gamma$-glutamiltransferase (Tabela 12).

Houve efeito linear crescente $(\mathrm{P}<0,05)$, com a adição de monensina sódica nas rações sobre a uréia e nitrogênio uréico do soro. Desta forma, aminoácidos não-essenciais são absorvidos no epitélio intestinal e podem ser utilizados como substrato para a gliconeogênese, onde a deaminação subseqüente destes aminoácidos resultam em maiores concentrações de uréia no soro (DUFFIELD et al., 1998).

Mesmo não se observando efeito $(\mathrm{P}>0,05)$ para níveis de glicose plasmática, os mesmos se mostraram elevados para todas as rações, estando de acordo com os valores de referência relatados por Rebhun e Chuck (2000), que citaram que os níveis séricos de glicose para vacas lactantes encontram-se entre 45,00 a 75,00 mg/dl.

Segundo Duffield et al. (2008), a utilização de monensina sódica na ração de vacas leiteiras pode resultar em aumento de 3,0\% da concentração de glicose plasmática em vacas leiteiras, se relacionando também com a fase de lactação e dose de monensina recebida pelos animais. Tem sido relacionado aumento de glicose plasmática especialmente em vacas em início de lactação.

A alteração no perfil fermentativo ruminal causada pelo uso de monensina pode aumentar a concentração de propionato no rúmen e a que chega ao fígado, estimulando a gliconeogênese e elevando os níveis de glicose plasmática. Porém, tal fato não ocorreu para os níveis de monensina utilizados neste experimento. Segundo Duffield et al. (2008), a utilização de monensina sódica na ração de vacas leiteiras pode resultar em aumento de 
$3,0 \%$ da concentração de glicose plasmática em vacas leiteiras, se relacionando também com a fase de lactação e dose de monensina recebida pelos animais. Tem sido relacionado aumento de glicose plasmática especialmente em vacas em início de lactação.

Segundo Pogliani e Birgel Jr. (2007), os valores de referência para colesterol total de vacas Holandesas lactantes é de 133,50 (mg/dl). Os resultados encontrados neste trabalho mostram valores elevados para colesterol total, muito provavelmente justificado pelo estágio de lactação e nível de produção de leite dos animais avaliados, essas variáveis podem ter relação com os níveis de colesterol elevados devido à físiologia de mobilização de reservas corporais dos animais ao longo da lactação e produção de leite.

O aumento na concentração plasmática de glicose está relacionado ao aumento de propionato que chega ao fígado, em decorrência da mudança do perfil fermentativo ruminal da monensina, o que não foi encontrado neste estudo (MARTINEAU et. al., 2007).

Não houve efeito $(\mathrm{P}>0,05)$ das rações experimentais sobre as concentrações no soro de proteína total e albumina, sendo os valores encontrados um pouco menores que os descritos por Rebhun e Chuck (2000), que são de 7,00 a 8,50 g/dl para proteínas totais e de 3,03 a 3,55 g/dl para albumina. Os resultados de Martineau et al. (2007) mostram maior concentração no soro de proteínas totais, sendo de $7,47 \mathrm{~g} / \mathrm{dl}$, e valores semelhantes em relação à concentração no soro de albumina, sendo de 3,55 g/dl.

Os níveis de uréia e nitrogênio uréico no soro apresentaram-se numericamente mais elevados para as rações com monensina sódica. Porém, os valores obtidos encontram-se de acordo com Rebhun e Chuck (2000), onde os valores de uréia e nitrogênio uréico no soro podem chegar a até $64,2 \mathrm{mg} / \mathrm{dl}$ e $30 \mathrm{mg} / \mathrm{dl}$, respectivamente, para vacas em lactação. Os valores acima são de referência para animais clinicamente saudáveis, no entanto, segundo Abe et al. (1994), para o adequado desempenho reprodutivo de vacas em lactação os valores encontrados neste trabalho estão acima dos preconizados. 
De acordo com Duffield et al. (2008), a adição de monensina na ração de vacas em lactação pode aumentar os níveis de uréia plasmática em 6\%. As concentrações de uréia mais altas podem ser resultado de maior concentração de proteína não degradada no rúmen (PNDR) chegando ao intestino delgado. A monensina causa redução na degradação da proteína no rúmen, provendo mais PNDR ao intestino delgado.

Tabela 12 -Médias e erro padrão da média (EPM) das concentrações de glicose (GLI), colesterol total (COT), colesterol HDL (C-HDL), uréia (URE), nitrogênio uréico no soro (NUS), proteínas totais (PTN), albumina, em função das rações experimentais

\begin{tabular}{|c|c|c|c|c|c|c|c|c|}
\hline \multirow{2}{*}{ Variáveis } & \multicolumn{4}{|c|}{ Rações experimentais $^{1}$} & \multirow{2}{*}{ Média } & \multirow[t]{2}{*}{ EPM } & \multicolumn{2}{|c|}{$P^{2}$} \\
\hline & $\mathrm{C}$ & M12 & M24 & M48 & & & $\mathrm{L}$ & Q \\
\hline \multicolumn{9}{|c|}{$\mathrm{mg} / \mathrm{dl}$} \\
\hline GLI & 62,61 & 57,73 & 60,99 & 59,08 & 60,10 & 1,72 & 0,634 & 0,668 \\
\hline COT & 203,71 & 232,35 & 202,20 & 242,74 & 220,25 & 8,23 & 0,149 & 0,656 \\
\hline $\mathrm{C}-\mathrm{HDL}^{3}$ & 60,09 & 70,21 & 67,07 & 64,94 & 65,57 & 2,01 & 0,405 & 0,054 \\
\hline Uréia & $44,12^{b}$ & $47,67^{\mathrm{ab}}$ & $45,60^{\mathrm{ab}}$ & $51,62^{\mathrm{a}}$ & 47,25 & 1,29 & 0,019 & 0,512 \\
\hline NUS & $20,61^{b}$ & $22,27^{\mathrm{ab}}$ & $21,31^{\mathrm{ab}}$ & $24,12^{\mathrm{a}}$ & 22,07 & 0,60 & 0,019 & 0,512 \\
\hline \multicolumn{9}{|c|}{$\mathrm{g} / 1$} \\
\hline PTN & 6,57 & 6,34 & 6,81 & 6,54 & 6,56 & 0,07 & 0,451 & 0,876 \\
\hline Albumina & 2,39 & 2,41 & 2,32 & 2,39 & 2,37 & 0,03 & 0,582 & 0,426 \\
\hline \multicolumn{9}{|c|}{$\mathrm{U} / \mathrm{L}$} \\
\hline $\mathrm{AST}^{4}$ & 75,66 & 80,71 & 78,25 & 93,81 & 82,10 & 4,40 & 0,146 & 0,509 \\
\hline $\mathrm{GGT}^{5}$ & 7,47 & 8,47 & 8,12 & 8,26 & 8,08 & 0,27 & 0,254 & 0,286 \\
\hline
\end{tabular}

${ }^{1}$ Controle (C); M12, M24 e M48, inclusão de 12, 24 e $48 \mathrm{mg} / \mathrm{Kg}$ de MS de Monensina sódica na dieta total, respectivamente. ${ }^{2}$ Probabilidades de resposta linear (L) ou quadrática (Q). Médias seguidas de letras diferentes nas linhas se diferenciam em 5\% no Teste de Tukey ajustado pelo PROC MIXED. ${ }^{3}$ Colesterol lipoproteína de alta densidade; ${ }^{4} \mathrm{AST}$ : aspartato aminotransferase; ${ }^{5} \mathrm{GGT}$ : gama glutamil transferase.

Os valores de uréia encontrados no presente estudo são maiores do que os obtidos por Abe et al. (1994), Martineau et al. (2007), Petersson-Wolfe et al. (2007) e Zahra et al. (2006), sendo de 35,02;28,30;29,04; 25,92 mg/dl, respectivamente. No entanto, são semelhantes aos 40,19 mg/dl obtidos por Ramanzin et al. (1997) e menores do que os 62,27 $\mathrm{mg} / \mathrm{dl}$ de uréia no soro obtidos por Gallardo et al. (2006). Assim, os valores de uréia no soro para vacas em lactação com adição de monensina são divergentes nos estudos citados na literatura, pois dependem do estágio de lactação, nível de produção e ração basal dos experimentos citados. 
Segundo Rebhun e Chuck (2000) os valores de referência para as enzimas aspartato aminotransferase e $\gamma$-glutamiltransferase são de 34,76 e 17,40 U/L, respectivamente, para vacas leiteiras em lactação. Os resultados obtidos no presente trabalho, com concentrações médias de 45,18 e 19,07U/L para as enzimas aspartato aminotransferase e $\gamma$ glutamiltransferase, respectivamente, são próximas as concentrações citadas como referência. No entanto, numericamente foram observados valores mais elevados para as rações com monensina, comprovando intenso metabolismo hepático de nutrientes com adição de monensina nas rações, sendo justificado pela maior produção de leite dos animais que receberam a dieta M24.

Martineau et al. (2007) observaram valores mais elevados do que os observados no presente estudo para aspartato aminotransferase e $\gamma$-glutamiltransferase, respectivamente, de 99,40 e 37,50 U/1, quando suplementou vacas leiteiras no terço médio de lactação com 24 $\mathrm{mg} / \mathrm{kg}$ MS de monensina. Provavelmente, o resultado encontrado por Martineau et al. (2007) se deve ao maior nível de produção dos animais neste trabalho.

\subsection{RESÍDUO DE MONENSINA SÓDICA NO LEITE}

A avaliação do resíduo de monensina sódica no leite resultou em concentrações no leite abaixo de $2 \mu \mathrm{g} / \mathrm{L}$, com as rações M12 (12 mg/kg MS), M24 (24 mg/kg MS) e M48 (48 mg/kg MS) apresentando, respectivamente, 0,039;0,040;0,049 e 0,922 $\mu \mathrm{g} / \mathrm{L}$. Apesar de na ração M48 ter sido utilizado o dobro da dose máxima de monensina sódica recomendada nas rações de vacas leiteiras, não houve aumento das concentrações de 
monensina no leite superior ao permitido por diferentes agências reguladoras de resíduos em produtos de origem animal.

É importante salientar que segundo o Codex Alimentarius Comission da Food and Agriculture Organization of United Nations (FAO-ONU) e da World Health Organization, na $17^{\mathrm{a}}$ reunião do Comite Codex de Resíduos de Drogas utilizadas por médicos veterinários e avaliação de resíduos em alimentos, em setembro de 2007, foi aprovado que o limite máximo de resíduos de monensina sódica no leite, em diversos países membros deste comitê é de $10 \mathrm{ppb}$, dependendo do país-membro, incluindo os Estados Unidos, Austrália, Canadá, China, Japão, Corea do Sul, Nova Zelândia, África do Sul e Taiwan.

De forma semelhante, segundo a European Medicines Agency, reunida em 15 de maio de 2007, o Committee for Medicinal Products for Veterinary Use recomendou o limite máximo para detecção de monensina sódica no leite na regulamentação Council Regulation (EEC) No 2377/90. O limite permitido é de $2 \mu \mathrm{g} / \mathrm{L}$, sendo, portanto, mais rigoroso, inclusive, do que o Codex Alimentarius Comission da Food and Agriculture Organization of United Nations (FAO-ONU) e da World Health Organization.

Desta forma Gandra (2009), apresentou limites de detecção de resíduos de monensina no leite inferiores ao permitido em diferentes agências reguladoras, mesmo com a utilização do dobro da dose máxima recomendada para vacas leiteiras. Outros autores, como Bagg et al. (2005), também observaram os mesmos resultados.

Desta forma, a concentração de monensina sódica no leite encontrada neste estudo está de acordo com o recomendado, sendo a concentração observada no leite das vacas submetidas a dietas contendo monensina menores do que o limite máximo aceitável. 


\section{CONCLUSÕES}

A utilização de monensina sódica nas rações de vacas leiteiras, tendo como volumoso a silagem de milho, melhorou o desempenho produtivo dos animais dependendo da dose utilizada.

Tendo em vista os resultados do desempenho produtivo indica-se a dose de 12 a 24 $\mathrm{mg} / \mathrm{kg}$ MS de monensina sódica para vacas no terço médio de lactação. A dose de $48 \mathrm{mg} / \mathrm{kg}$ MS não deve ser indicada, visto a forte queda do consumo de matéria seca, juntamente com a redução do desempenho produtivo dos animais.

A monensina sódica nas doses utilizadas neste estudo, não apresentaram resíduos no leite capazes de ultrapassar o limite máximo estabelecido pela $\mathrm{FAO} / \mathrm{WHO}$, como sendo prejudicial para saúde humana, desta forma, podendo ser utilizado na pecuária de leite sem qualquer risco à saúde humana. 


\section{REFERÊNCIAS}

ABE, N.; LEAN, I. J.: RABIEE, A.; PORTER, J.; C. GRAHAM, C. Effects of sodium monensin on reproductive performance of dairy cattle. Ii. Effects on metabolites in plasma, resumption of ovarian cyclicity and oestrus in lactating cows. Australian Veterinary Journal, v. 71, p. 277-282, 1994.

ALI HAIMOUD, D.; VERNAY, M.; BAYOURTHE, C.; MONCOULON, R. Avoparcin and monensin effects on the digestion of nutrients in dairy cows fed a mixed diet. Canadian Journal of Animal Science, v. 75, p. 379-385, 1995.

ALLEN, M. S. Effects of Diet on Short-Term regulation of feed Intake by lactating dairy cattle. Journal of Dairy Science, v. 83, n. 7, p. 1598-1630, 2000.

ALZAHAL, O.; ODONGO, N. E.; MUTSVANGWA, T.; OR-RASHID, M. M.; DUFFIELD, T. F.; BAGG, R.; P. DICK, P.; G. VESSIE, G.; MCBRIDE, B. W. Effects of monensin and dietary soybean oil on milk fat percentage and milk fatty acid profile in lactating dairy cows. Journal of Dairy Science, v. 91, p. 1166-1174, 2008.

AOAC. ASSOCIATION OF OFFICIAL ANALYTICAL CHEMISTS. Official methods of analysis Arlington. 11. ed. Washington: FALTA EDITORA, 1995. 1050 p.

BADWAY, S. A.;YONIS, M.; SHALASH, M. R. et. Al. Monensin effects on rumen metabolic profile, methane production and protozoal population in buffalo heifers.

Egyptian Journal of Veterinary Science, v.30, p.49-56, 1996.

BAGG, R.; VESSIE, G. H.; DICK, C. P.; DUFFIELD, T.; WILSON, J. B.; ARAMINI, J. J. Milk residues and performance of lactating dairy cows administered high doses of monensin. The Canadian Journal of Veterinary Research, v. 69, p. 180-185, 2005.

BARBANO, D. M.; CLARK, J. L. Kjeldahl method for determination of total nitrogen content of milk: collaborative study. Journal AOAC International, v. 73, p. 849-859, 1990.

BARMAN, K.; MOHINI, M.; SENGHAL, K. Indian Journal of Animal Nutrition, v.18, n.4, p.325-329, 2001.

BAUMAN, D. E.; GRIINARI, J. M. Regulation and nutritional manipulation of milk fat: low-fat milk syndrome. Livestock Production Science, v. 70, p. 15-29, 2003.

BECKETT, S.; LEAN, I.; DYSON, R.; TRANTER, W.; WADE, L. Effects of monensin on the reproduction, health, and milk production of dairy cows. Journal of Dairy Science, v. 81, p. 1563-1573. 1998. 
BELL, J. A.; GRIINARI, J. M.; KENNELLY, J. J. Effect of safflower oil, flaxseed oil, monensin, and vitamin $\mathrm{E}$ on concentration of conjugated linoleic acid in bovine milk fat. Journal of Dairy Science, v.89, p.733- 748, 2006.

BENCHAAR, C.; PETIT, H.V.; BERTHIAUME, R. Effects of addition of essential oils and monensin premix on digestion, ruminal fermentation, milk production, and milk composition in dairy cows. Journal of Dairy Science, v. 89, p. 4352-4364, 2006.

BERGEN, W. G., BATES, D. B. Ionophores: Their effect on production, efficiency and mode of action. Journal of Animal Science v.58, p.1453-1465. 1984.

BIGGS, H. G.; COOPER, J. M. An evaluation of four methods of measuring urinary creatinine. Clinical Chemistry, v. 7, p. 665-673, 1961.

BLANCHFLOWER, W. J.; KENNEDY, D. G. Determination of monensin, salinomycin and narasin in muscle, liver and eggs from domestic fowl using liquid chromatographyelectrospray mass spectrometry. Journal of Chromatography Biology Biomedical Application, v. 26, p. 225-233, 1996.

BRODERICK, G. A. Effect of low level monensin supplementation on the production of dairy cows fed alfalfa silage. Journal of Dairy Science, v. 87, p. 359-368, 2004.

CAMPOS NETO, O.; RAMOS, A. A.; ESCOBAR, M. J. et. al. Avaliação da monensina sódica em vacas leiteiras. Science Agricultural, v.52, p.268-273, 1995.

CASALI, A. O. Procedimentos metodológicos in situ na avaliação do teor de compostos indigestiveis em alimentos e fezes de bovinos.47 p. Dissertação (Mestrado) - Universidade Federal de Viçosa, Viçosa, 2006.

CHALUPA, W. Manipulating ruminal fermentation. Journal of Animal Science, v.45, p.585-599, 1977.

CHEN, M.; RUSSELL, J. B. More monensin-sensitive, ammonia producing-bacteria from the rumen. Application. Environment. Microbiology, v. 55, p. 1052-1065, 1989.

CHEN, X. B.; GOMES, M. J. Estimation of microbial protein supply to sheep and cattle based on urinary excretion of purine derivatives - an overview of technical details. (Occasional publication). In: INTERNATIONAL FEED RESEARCH UNIT, 1992, Bucksburnd, Aberdeen: Rowett Research Institute, 1992.

CHÉNEAU, E.; HENRI, J.; PIROTAIS, Y.; ABJEAN, J. P.; ROUDAUT, B.; SANDERS, P.; LAURENTIE, M. Liquid chromatography-electrospray tandem mass spectrometric method for quantification of monensin in plasma and edible tissues of chicken used in pharmacokinetic studies: applying a total error approach. Journal of Chromatography Biology Analytical Technology Biomedical Life Science, v. 1, n. 850, p. 15-23, 2006. 
CHIZZOTTI, M. L. Avaliação da casca de algodão para novilhos de origem leiteira e determinação da excreção de creatinina e produção de proteína microbiana em novilhas e vacas. 2004. 132 p. Dissertação (mestrado em zootecnia) - Universidade Federal de Viçosa, Viçosa, 2004.

COELHO, D. T.; ROCHA, J. A. A. Práticas de processamento de produtos animais. Viçosa, MG: Universidade Federal de Viçosa, 1977. 79p.

DA SILVA, D. C.; SANTOS, G. T. ; BRANCO, A. F.; DAMASCENO, J. C.; KAZAMA, R.; MATSUSHITA,M.; HORST, J. A.; DOS SANTOS, W. B. R.; PETIT, H. V. Production performance and milk composition of dairy cows fed whole or ground flaxseed with or without monensin. Journal of Dairy Science, v. 90, p. 2928-2936, 2008.

DUBUC, J.; DUTREMBLAY, D.; BRODEUR, M.; DUFFIELD, T.; BAGG, R.; BARIL, J.; DESCÔTEAUX, L. A randomized herd-level field study of dietary interactions with monensin on milk fat percentage in dairy cows. Journal of Dairy Science, v. 92, p. 777$781,2009$.

DUFFIELD, T. F.; BAGG. R. N. Use of ionophores in lactating dairy cattle: a review. Canadian Veterinary Journal, v. 41, p. 388-394, 2000.

DUFFIELD, T. F.; LESLIE, K. E.; SANDALS, D. Effect of a monensin controlled release capsule on cow health and reproductive performance. Journal of Dairy Science, v. 82, p. 2377-2388, 1999.

DUFFIELD, T. F.; SANDALS, D.; LESLIE, K. E. Effect of prepartum administration of monensin in a controlled-release capsule on postpartum energy indicators in lactating dairy cows. Journal of Dairy Science, v. 81, p. 2345-2354, 1998a

DUFFIELD, T. F.; SANDALS, D.; LESLIE, K. E. Efficacy of monensin for the prevention of sub clinical ketosis in lactating dairy cows. Journal of Dairy Science, v. 81, p. 28552866, 1998 b.

DUFFIELD, T.; BAGG, R.; KELTON, D.; DICK, P.; WILSON, J. A field study of dietary interactions with monensin on milk fat percentage in lactating dairy cattle. Journal of Dairy Science, v. 86, p. 4161-4166, 2002.

DUFFIELD, T. F.; RABIEE, A. R.; LEAN, I. J. A meta-analysis of the impact of monensin in lactating dairy cattle. Part ${ }^{2}$. Production effects. Journal of Dairy Science, v. 91, p. 13471360, 2008.

EDMONSON, A. J.; LEAN, I. J.; WEAVER, L. D.; FARVER, T.; WEBSTER, G. A body condition scoring chart for Holstein dairy cows. Journal of Dairy Science, v. 72, n. 1, p. 68-78, 1989.

EIFERT, E. C; LANA, R. P.; LANNA, D. P. D. Efeito do fornecimento de dietas com monensina e óleo de soja no desempenho de vacas leiteiras na fase inicial de lactação.

Revista Brasileira de Zootecnia, v. 34, n. 6, p. 2123-2132, 2005. 
ERASMUS, L. J.; MUYA, C.; ERASMUS, S.; COERTZE, R. F.; CATTON, D.G Effect of virginiamycin and monensin supplementation on performance of multiparous Holstein cows, Livestock Science, 2008. doi:10.1016/j.livsci.2008.03.005.

FRIEDEWALD, W. T.; LEVY, R. L.; FREDRICKSON, D. L. Estimation of the concentration of low-density lipoprotein cholesterolin plasma, without use of the preparative ultracentrifuge. Clinical Chemistry, v. 18, p. 499-502, 1972.

FUJIHARA, T.; ORSKOV, E. R.; REEDS, P. J. et. al. The effect of protein infusion on urinary excretion of purine derivates in ruminants nourished by intragastric nutrition. Journal of Dairy Science, v.109, p.7-12, 1987.

GALLARDO, M. R.; CASTILLO, A. R.; BARGO, F. Monensin for lactating dairy cows grazing mixed-alfalfa pasture and supplemented with partial mixed ration. Journal of Dairy Science, v. 88, p. 644-652, 2005.

GANDRA, J. R. Avaliação do uso de monensina sódica em rações de vacas leiteiras: desempenho produtivo e resíduo no leite. 93 p. Dissertação (Mestrado em Medicina Veterinária). Faculdade de Medicina Veterinária e Zootecnia, Universidade de São Paulo. Pirassununga, SP. 2009.

GANDRA, J. R.; RENNÓ, F. P.; SILVA, L. F. P. et. al. Parâmetros sanguíneos de vacas leiteiras submetidas à diferentes níveis de monensina sódica nas rações. Revista Brasileira de Saúde e Produção Animal, v.10, n.1, p.115-128, 2009.

GEHMAN, A.; M.; KONONOFF, P. J.; MULLINS, C. R. ; JANICEK, B. N. Evaluation of nitrogen utilization and the effects of monensin in dairy Cows fed brown midrib corn silage. Journal of Dairy Science, v. 91, p. 288-300, 2008.

GONZÁLEZ-RONQUILLO, M.; BALCELLS, J.; GUADA, J.A. Purine derivative excretion in dairy cows: Endogenous excretion and the effect of exogenous nucleic acid supply. Journal of Dairy Science, v.86, n.4, p.1282-1291, 2004.

GRANZIN, B. C.; DRYDEN, G. M. C. L. Monensin supplementation of lactating cows fed tropical grasses and cane molasses or grain. Animal Feed Science and Technology, v. 120, p. 1- 16, 2005.

GREEN, B. L.; MCBRIDE, B. W.; SANDALS, D. The impact of a monensin controlledrelease capsule on sub clinical ketosis in the transition dairy cow. Journal of Dairy Science, v. 82, p. 323-333, 1999.

HALL, M. B. Making nutritional sense of nonstructural carbohydrate. In: ANNUAL FLORIDA RUMINANT NUTRITION SYMPOSIUM, 9., 1998, Gainsville, Fl.

Proceedings... Gainsville: Florida University Press, 1998. p. 108-121.

HANEY, Jr. M, E.; HOEHN, M. M. Monensin, a new biologically active compound. I. Discovery and isolation. Antimicrobial Agents Chemother, p.349, 1967. 
HARVATINE, K. J.; ALLEN, M. S. Effects of Fatty Acid Supplements on Milk Yield and Energy Balance of Lactating Dairy Cows. Journal of Dairy Science, v. 89, p.1081-1091, 2006.

HAYES, D. P.; PFEIFFER, D. U.; WILLIAMSON, N. B. Effect of intraruminal monensin capsules on reproductive performance and milk production of dairy cows fed pasture. Journal of Dairy Science, v.79, p.1000-1008, 1996.

HEINRICHS, A. J.; BUSH, G. J. Evaluation of decoquinate or lasalocid against natural exposure in neonatal dairy calves. Journal of Dairy Science, v.74, p.3223-3227, 1991.

HERGAZY, M. A. Influence of monensin on blood metabolite and reproductive of suckeled buffalo cows. Assiut Veterinary Medical Journal, v.36, n.72, p.313-325, 1997.

HEUER, C.; SCHUKKEN, Y. H.; JONKER, L. J. et al. Effect of monensin on blood ketone bodies incidence and recurrence of disease and fertility in dairy cows. Journal of Dairy Science, v.84, p.1085-1097, 2001.

HINO, T.; RUSSELL, J. B. Relative contribuitions of ruminal bacteria and protozoa to the degradation of protein in vitro. Journal of Animal Science, v. 64, p. 248-261, 1986.

IDF. INTERNATIONAL DAIRY FEDERATION. Whole milk. Determination of milk fat, protein and lactose content Guide for the operation of mid-infra-red instruments. Bruxelas: IDF, 1996. 12 p. (IDF Standard 141 B).

IPHARRAGUERRE, I. R.; CLARK, J. H. Usefulness of ionophores for lactating cows: a review. Animal Feed Science and Technology, v. 106, p. 39-57, 2003.

KRAUSE, D. O.; RUSSELL, J. B. An rRNA approach for assessing the role of obligate amino acid-fermenting bacteria in ruminal amino acid degradation. Appl. Envi. Micr. v.62, p.815. 1996.

KENNELLY, J. J.; LIEN, K. A. Effect if ionophore supplementation on milk components from lactating cows. In: A SYMPOSIUM HELD, 1. ONTARIO: Ontario Veterinary college, p. 40-49, 1997.

LACETERA, N.; SCALIA, D.; FRANCI, O. et al. Short communucation: Effects of nonesterified fatty acids on lymphocyte function in dairy heifers. Journal of Dairy Science, v. 87, p.1012-1014, 2004.

LEAN, I. J.; CURTIS, M.; DYSON, R. Effects of sodium monensin on reproductive performance of dairy cattle. I- Effects on conception rates, calving to conception intervals, calving to heat and milk production in dairy cows. Australian Veterinary Journal, v.71, n.9, p.273-277, 1994. 
LEAN, I. J.; WADE, L. Effects of monensin on metabolism, production and health of dairy cattle. Usefulness of Ionophores in Lactating Dairy Cattle. University of Guelph, Guelph, Ontario, Canada, p.50-70, 1997.

LYNCH, J. M.; BARBANO, D. M. Indirect and direct determination of the casein content of milk by kjeldahl nitrogen analysis: collaborative study. Journal AOAC International, v. 81, p. 763-774, 1998.

MACKINTOSH, E. D., PHIPPS, R. H., SUTTON, J. D. The effects of monensin and diet composition on methane production using the in vitro semicontinuos rumen simulation technique (Rusitec). Journal of Dairy Science, v. 80, p. 208, 1997. Supplement.

MARTINEAU, R.; BENCHAAR, C.; PETIT, H. V. Effects of lasalocid or monensin supplementation on digestion, ruminal fermentation, blood metabolites, and milk production of lactating dairy cows. Journal of Dairy Science, v. 90, p. 5714-5725, 2007.

McCLARY, D. G.; GREEN, E. E.; THOMAS, J. I. D. descrever os demais autores et al. Effect of rumensin on performance and health in lactating dairy cows. In: FOUR STATE NUTRITION AND MANAGEMENT CONFERENCE, 2005, Dubuque. Proceeding... Dubuque: Iowa State University, 2005. p. 255-264.

McDOUGALL, S.; YOUNG, L.; ANNISS, F. M. Production and health of pasture-fed dairy cattle following oral treatment with the ionophore lasalocid. Journal of Dairy Science, v.87, p.2967-2976, 2004.

McGUFFEY, R. K.; RICHARDSON, L. F.; WILKINSON, J. I. D. Ionophores for dairy cattle: current status and future outlook. Journal of Dairy Science, v.84, Supplement, p.194-203, 2001.

MERTENS, D. R. Gravimetric determination of amylase-treated neutral detergent fiber in feeds with refluxing beakers or crucibles: collaborative study. Journal of AOAC

International, v. 85, p. 1217-1240, 2002.

MOSCARDINI, S.; WRIGHT, T. C.; LUIMES, P. H. Effects of rumen undegradable protein and feed intake on purine derivative and urea nitrogen: comparison with predictions from the Cornell Net Carbohydrate and Protein System. Journal of Dairy Science, v. 81, n. 9, p. 2421-2429, 1998

NAGAJARA, T. G., AVERY, T. B., BARTLEY, E. E. Effect of lasalocid, monensin, or thiopeptin on lactic acidosis in cattle. Journal of Animal Science v.54, p.637- 649. 1981.

NOCEK, J. E. In situ and other methods to estimate ruminal protein and energy digestibility. A review. Journal of Dairy Science, v. 71, p. 2051-2069, 1988.

NRC. NATIONAL RESEARCH COUNCIL. Nutrient requirements of dairy cattle. 7. ed. Washinton, D.C.: National Academic Press, 2001. 381 p. 
OBA, M.; ALLEN, M. S. Dose-response effects of intraruminal infusion of propionate on feeding behavior of lactating cows in early or midlactation. Journal of Dairy Science, v. 86, p. 2922-2931, 2003.

OELKER, E. R.; REVENEAU, C.; FIRKINS, J. L. Interaction of molasses and monensin in alfalfa hay or corn silage-based diets on rumen fermentation, total tract digestibility, and milk production by Holstein cows. Journal of Dairy Science, v. 92, p. 270-285, 2009.

OLIVEIRA, A. S.; VALADARES, R. F. D.; FILHO, S. C. V.; CECON, P. R.; RENNÓ, L. N.; QUEIROZ, A. C.; CHIZZOTTI, M. L. Produção de proteína microbiana e estimativas das excreções de derivados de purinas e de uréia em vacas lactantes alimentadas com rações isoprotéicas contendo diferentes níveis de compostos nitrogenados não-protéicos. Revista Brasileira de Zootecnia, v. 30, n. 5, p. 1621-1629, 2001.

OLIVEIRA, N. J. F.; MELO, M. M.; LAGO, L. A. NASCIMENTO, E. F. Hemograma, bioquímica sérica e histologia da biópsia hepática de bovinos após administração de polpa cítrica. Arquivo Brasileiro de Medicina Veterinária e Zootecnia, v. 57, n.3, p.418-422, 2005.

ORELLANA BOERO, P.; BALCELLS, J.; MARTÍN-ORÚE, S. M. Excretion of purine derivates in cows: endogenous contribution and recovery of exogenous purine bases.

Livestock Production Science, v. 68, p. 243-250, 2001.

OSBORNE, J. K.; MUTSVANGWA, T.; ALZAHAL, O.; DUFFIELD, T. F.; BAGG, R.; DICK, P.; VESSIE, G.; MCBRIDE, B. W. Effects of monensin on ruminal forage degradability and total tract diet digestibility in lactating dairy cows during grain-induced subacute ruminal acidosis. Journal of Dairy Science, v. 87, p. 1840-1847, 2004.

PETERSSON-WOLFE, C. S.; LESLIE, K. E.; OSBORNE, T. Effect of delivery method of monensin on dry matter intake, body condition score, and metabolic parameters in transition dairy cows. Journal of Dairy Science, v. 90, p. 1870-1879, 2007.

PHIPPS, R. H.; WILKINSON, J. I.; JONKER, L. J. Effect of monensin on milk production of Holstein-Friesian dairy cows. Journal of Dairy Science, v. 83, p. 2789-2794, 2000.

PLAZIER, J. C.; MARTIN, A.; DUFFIELD, T. Effect of a prepartum administration of monensin in a controlled capsule on apparent digestibilities and nitrogen utilization in transition dairy cows. Journal of Dairy Science, v. 83, p. 2906-2918, 2000.

POGLIANI, F. C.; BIRGEL JR., E. Valores de referência do lipidograma de bovinos da raça holandesa, criados no estado de São Paulo. Brazilian Journal of Veterinarian Research and Animal Science, v. 44, n. 5, p. 373-383, 2007.

PRESSMAN, B. C. Ionophorus antibiotics as models for biological transport. Federation proceedings, Bethesda, v. 27, p. 1283-1288, 1968. 
RAMANZIN, M.; BAILONI, L.; SCHIAVON, S. Effect of monensin on milk production and efficiency of dairy cows fed two diets differing in forage to concentrate ratios. Journal of Dairy Science, v.80, p. 1136-1142, 1997.

REBHUM, W.C.; GUARD, C. Doenças de gado leiteiro. São Paulo: Rocca, 2000. 642 p.

RENNÓ, L. N. Consumo, digestibilidade total e parcial, produção microbiana, parâmetros ruminais e excreções de uréia e creatinina em novilhos alimentados com dietas contendo quatro níveis de uréia ou dois de proteína. 2003. 252 p. Tese (Doutorado em Zootecnia) Universidade Federal de Viçosa, Viçosa, 2003.

RUIZ, R.; ALBRECHET, G. L.; TEDESCHI, L. O. et. al. Effect of monensin on the performance and nitrogen utilization of lacting dairy cows consuming fresh forage. Journal of Dairy Science, v.84, p.1717-1727, 2001.

RUSSELL, J. B. A proposed model of monensin action in inhibiting rumen bacterial growth: effects on ion flux and proton motive force. Journal of Animal Science, v. 64. p. 1507-1519, 1988.

RUSSELL, J. B. Mechanisms of ionophore action in ruminal bacteria. In: Symposium Elanco Animal Health - Scientific Update on Rumensin/Tylan/Micotil for the Professional Feedlot Consultant, 1996, Amarillo. Proceedings... Amarillo: ELANCO, 1996. p. 315.

RUSSELL, J. B.; MARTIN, S. A. Effects of various methane inhibitors on the fermentation of amino acids by mixed rumen microorganisms in vitro. Journal of Animal Science, v. 59, p. 1317-1329, 1984.

RUSSELL, J. B.; STROBEL, H. J. Mini review. Effect of ionophores on ruminal fermentation. Applied and Environmental Microbiology, v.55, p.1-6, 1989.

SAS. STATISTICAL ANALISYS/STAT. SAS user's guide: statistics. . Release 8.0 Cary: SAS, 1999. $1500 \mathrm{p}$.

SAUER, F. D.; FELLNER, V.; KINSMAN, R. Methane output and lactation response in Holstein cattle with monensin or unsaturated fat added to the diet. Journal Animal Science, v. 76, p. 906-914, 1998.

SAUER, F. D.; KRAMER, J. K. G.; CANTWELL, W. J. Antiketogenic effects of monensin in early lactation. Journal of Dairy Science, v. 72, p. 423-436, 1989.

SCHELLING, G. Monensin mode of action in the rumen. Journal of Animal Science, v. 58, p. 1518-1527, 1984.

SILVA, D. J.; QUEIROZ, A. C. Análise de alimentos (métodos químicos e biológicos). Viçosa: UFV, Impr. Univ., 2002. 235 p. 
SKLAN, D.; ASHKENAZI, R.; BRUN, A.; DEVORIN, A.; TABORI, K. Fatty acids, calcium soaps of fatty acids, and cottonseeds fed to high yielding cows. Journal of Dairy Science, v. 75, p. 2463-2472, 1992.

SLYTER, L. L. Influence of acidosis on rumen function. Journal of Animal Science, v. 43, p. 899-910, 1976.

SNIFFEN, C. J.; O'CONNOR, J. D.; VAN SOEST, P. J. et al. A net carbohydrate and protein system for evaluating cattle diets. Ii. Carbohydrate and protein availability. Journal of Animal Science, v. 70, n. 11, p. 3562-3577, 1992.

SPEARS, J. W. Ionophores and nutrient digestion and absorption in ruminants. Journal of Nutrition, v.120, p. 620-632, 1990.

STEPHENSON, K. A.; LEAN, I. J.; HYDE, M. L. et al. Effects of monensin on the metabolism of periparturient dairy cows. Journal of Dairy Science, v.83, p.830-837, 1997.

SURIYASATHAPORN, W.; HEUER, C.; NOORDHUIZEN-STASSEN, E. Hyperketonemia and udder defense: A review. Veterinary Research, v.31, p.397-412, 2000 .

SYMANOWSKI, J. T.; GREEN, H. B.; WAGNER, J. R. et. al. Milk production and efficiency of cows fed monensin. Journal of Dairy Science, v. 82, p.75, 1999.

THORNTON, J. H.; OWENS, F. N. Monensin supplementation and in vivo methane production by steers. Journal of Animal Science, v. 52, p. 625-628, 1981.

VALADARES, R. F. D.; BRODERICK, G. A.; VALADARES FILHO, S. C. Effect of replacing alfalfa with high moisture corn on ruminal protein synthesis estimated from excretion of total purine derivatives. Journal of Dairy Science, v. 82, p. 2686-2696, 1999.

VALLIMONT, J. E.; VARGA, G. A.; ARIELI, A. et. al. Effects of prepartum somatrotopin and monensin on metabolism and production of preparturient holstein dairy cows. Journal of Dairy Science, v.84, p.2607-2621, 2001.

VAN NEVEL, C. J.; DEMEYER, D. I. Effect of monensin on rumen metabolism in vitro. Application Environment Microbiology, v. 34, p. 239-251, 1977.

VAN SOEST, P. J.; MASON, V. C. The influence of Maillard reaction upon the nutritive value of fibrous feeds. Animal Feed Science and Technology, v. 32, n. 1, p. 45-53, 1991.

VARGA, G. A.; KOLVER, E. Microbial and animal limitations to fiber digestion and utilization. Journal of Nutrition, v. 127, p. 819S-823S, 1997.

VAN DER MERWE, B. J.; DRUGMORE, T. J., WALSH, K. P. The effect of monensin on milk production, milk urea e body condition score of grazing dairy cows. South African Journal of Animal Science, v.31, n.1, p.49-55, 2001. 
VAN DER WERF, J. H. J.; JONKER, L. J.; OLDENBROEK, J. K. Effect of monensin on milk production by Holstein and Jersey cows. Journal of Dairy Science, v.81, p.427-433, 1998.

WEISS, W. P.; CONRAD, H. R.; PIERRE, N. R. S. T. A theoretically-based model for predicting total digestible nutrient values of forages and concentrates. Animal Feed Science Technology, v. 39, p. 95-110, 1992.

WILDMAN, O. E. E.; JONES, G. M.; WAGNER, P. E. A dairy cow body condition scoring system and its relationship to selected production characteristics. Journal of Dairy Science, v. 65, n. 3, p. 495-501, 1982.

WILKINSON, J. I. D.; KENNINGTON, A. S.; EHRENFRIED, K. M.; MORAN, J. W.; BUCK, J. M. Human food safety with the use of monensin in lactating dairy cows. In: SYMPOSIUM ON USEFULNESS OF IONOPHORES IN LACTATING DAIRY CATTLE, 1997, Canada. Proceedings... Canada: Ontario Veterinary College, Guelph, 1997. p. 86-93.

ZAHRA, L. C.; DUFFIELD, T. F.; LESLIE, K. E. Effects of rumen-protected choline and monensin on milk production and metabolism of periparturient dairy cows. Journal of Dairy Science, v. 89, p. 4808-4818, 2006. 